\title{
Insulin resistance and cancer: the role of insulin and IGFs
}

\author{
Sefirin Djiogue ${ }^{1}$, Armel Hervé Nwabo Kamdje ${ }^{2,3}$, Lorella Vecchio ${ }^{4}$, \\ Maulilio John Kipanyula ${ }^{5}$, Mohammed Farahna ${ }^{6}$, Yousef Aldebasi ${ }^{7}$ and \\ Paul Faustin Seke Etet ${ }^{6}$ \\ ${ }^{1}$ Department of Animal Biology and Physiology, University of Yaoundé 1, PO Box 812, Yaoundé, Cameroon \\ ${ }^{2}$ Biomedical Research Center, University of British Columbia, 2222 Health Science Mall, Vancouver, British Columbia, \\ Canada V6T 1 Z3 \\ ${ }^{3}$ Department of Biomedical Sciences, University of Ngaoundéré, PO Box 454, Ngaoundéré, Cameroon \\ ${ }^{4}$ Laboratory of Cytometry, University of Pavia, via Ferrata 1, 27100 Pavia, Italy \\ ${ }^{5}$ Department of Veterinary Anatomy, Sokoine University of Agriculture, PO Box 3016, Chuo Kikuu, Morogoro, \\ Tanzania \\ Departments of ${ }^{6}$ Basic Health Sciences ${ }^{7}$ Optometry, College of Applied Medical Sciences, Qassim University, \\ Buraydah, 51452 Al-Qaseem, Saudi Arabia
}

Correspondence should be addressed to P F Seke Etet Email paul.seke@gmail.com

\begin{abstract}
Insulin, IGF1, and IGF2 are the most studied insulin-like peptides (ILPs). These are evolutionary conserved factors well known as key regulators of energy metabolism and growth, with crucial roles in insulin resistance-related metabolic disorders such as obesity, diseases like type 2 diabetes mellitus, as well as associated immune deregulations. A growing body of evidence suggests that insulin and IGF1 receptors mediate their effects on regulating cell proliferation, differentiation, apoptosis, glucose transport, and energy metabolism by signaling downstream through insulin receptor substrate molecules and thus play a pivotal role in cell fate determination. Despite the emerging evidence from epidemiological studies on the possible relationship between insulin resistance and cancer, our understanding on the cellular and molecular mechanisms that might account for this relationship remains incompletely understood. The involvement of IGFs in carcinogenesis is attributed to their role in linking high energy intake, increased cell proliferation, and suppression of apoptosis to cancer risks, which has been proposed as the key mechanism bridging insulin resistance and cancer. The present review summarizes and discusses evidence highlighting recent advances in our understanding on the role of ILPs as the link between insulin resistance and cancer and between immune deregulation and cancer in obesity, as well as those areas where there remains a paucity of data. It is anticipated that issues discussed in this paper will also recover new therapeutic targets that can assist in diagnostic screening and novel approaches to controlling tumor development.
\end{abstract}

Endocrine-Related Cancer (2013) 20, R1-R17

\section{Introduction}

Insulin resistance is a pathological condition characterized by a decrease in efficiency of insulin signaling for blood sugar regulation. Insulin resistance is a major component of metabolic syndrome, i.e. a group of risk factors that generally occur together and increase the risk for various diseases, including type 2 diabetes mellitus and several other metabolic diseases (Campbell 2011, Karagiannis et al. 2012), cerebrovascular and coronary artery diseases (Hadaegh et al. 2012, Vykoukal \& Davies 2012), neurodegenerative disorders (Kaidanovich-Beilin et al. 2012, 
Talbot et al. 2012), infectious diseases (Jeon et al. 2012, Witso 2012), and cancer (Byers \& Sedjo 2011, Spyridopoulos et al. 2012). Due to the ongoing worldwide epidemic of obesity and other insulin resistance-related disorders (Campbell 2011), insulin-like peptides (ILPs), i.e. evolutionary conserved and ubiquitous factors historically involved in the regulation of energy metabolism, have been the subject of thorough investigations. In humans, ILPs include insulin, IGF1, IGF2, and seven relaxin-related peptides, which share the same basic fold (Sajid et al. 2011). In the present review, the term 'ILP' will be used to indicate insulin and IGFs, whereas relaxin-related peptides will not be discussed.

Insulin signal transduction occurs through two insulin receptor (IR) isoforms resulting from transcriptional alternative splicing: the ' $\mathrm{A}$ ' isoform (IR-A) that recognizes insulin and IGFs, with a greater affinity for IGF2 than IGF1, and the IR ' $\mathrm{B}$ ' isoform (IR-B), which is insulin specific and mainly involved in glucose homeostasis (Zhang \& Roth 1991, Artim et al. 2012). In healthy individuals, blood glucose concentrations are maintained within narrow physiological range by a state of balance between insulin production by specialized pancreatic $\beta$-cells and insulin-mediated glucose uptake in target tissues, which is further determined by the translocation of glucose transporters, of which GLUT- 4 is the most abundant, to the cell surface (Kern et al. 1990). Evidence that insulin resistance in classic insulin-target organs, together with the associated hyperglycemia and hyperinsulinemia (followed by hypoinsulinemia) are the pathological hallmark of metabolic disorders such as obesity and type 2 diabetes is compelling (Ricketts 1947, Berry \& Helwig 1948, Ahmed et al. 2012, Aldhafiri et al. 2012). Several population-based studies revealed a decrease in cancer risk in diabetic patients assuming antidiabetic agents of the biguanide family such as metformin (Pezzino et al. 1982, Suissa 2008, Kiri \& Mackenzie 2009). On the other hand, a growing body of evidence indicates an association between type 2 diabetes and an increase in risk of developing breast, prostate, colon, endometrial, and ovarian cancers (Alvino et al. 2011, Tan et al. 2011, Tzivion et al. 2011, Mu et al. 2012).

Data obtained from independent studies involving Drosophila model show that ILPs have specialized functions including regulating cell proliferation, differentiation, survival, and apoptosis, thus playing a pivotal role in cell fate determination and life span control (Bai et al. 2012, Bolukbasi et al. 2012). Such functions are evolutionarily conserved (Duckworth et al. 1989, Klusza \& Deng 2011), and accordingly, the stimulation of IGF1 axis may represent a common medium for both cancer and diabetes pathogenic processes, together with systemic inflammation and the associated increase in cytokine production (Nunez et al. 2006, Dool et al. 2011, Faria \& Almeida 2012, Ferguson et al. 2012, Fernandez-Real \& Pickup 2012, Gallagher et al. 2012). Except for the IGF2 receptor (IGF2R), following ligand binding, the kinase activity of ILP receptors is activated, leading to the phosphorylation of IR substrates in the cell membrane, which in turn i) activates phosphoinositide 3-kinase (PI3K)/protein kinase B (Akt)/mammalian target of rapamycin (mTOR), PI3K/Akt/forkhead box O (FoxO), and Ras/MAPK/extracellular signal-related kinase $1 / 2$ (ERK-1/2) pathways, whose important roles in cancer cell growth and carcinogenesis have been reported (Alvino et al. 2011, Tzivion et al. 2011); and ii) inactivates glycogen synthase kinase $3 \beta$ (GSK3 $\beta$ ), the inhibitor of the oncogenic $\beta$-catenin signaling, through PI3K/Akt signaling pathway, resulting in $\beta$-catenin signaling activation that has been associated with cancer stemness and chemoresistance (Fleming et al. 2008, Ashihara et al. 2009; see Fig. 1). Other ILP receptors include the IGF1 receptor (IGF1R) that recognizes both IGF1 and IGF2; holoreceptors made up of combinations of half IGF1R and IR isoforms or other tyrosine kinases; and finally the IGF2R that recognizes only IGF2 (Rinderknecht \& Humbel 1978) and attenuates IGF2 signaling by clearing the ligand from cell surface without signal transduction (Artim et al. 2012). IGFs also bind to carrier proteins named 'IGF-binding proteins' (IGFBP).

Contrary to insulin, IGFs are produced by many cell types, although the liver is their main site of production. IGF1 production in the liver is stimulated by GH (Blethen et al. 1981, Madsen et al. 1983). IGFs have characteristics of both hormones and tissue growth factors, and consequently, they can induce both local and systemic responses (Blundell et al. 1978, Sajid et al. 2011). Tissues that classically respond to IGFs preferentially express the IGF1R, and nonclassic target tissues including cancer cells express both the latter receptor and IR-A genes and may display hybrid receptors as well, which probably account in carcinogenesis and chemoresistance (Artim et al. 2012, Pierre-Eugene et al. 2012).

In the present review, we critically summarize recent reports indicating a crucial role of insulin, IGFs, and their receptors in cancer development and maintenance. A unifying model for the high cancer risks and chemoresistance associated with insulin resistance, in obesity and type 2 diabetes cases, will also be discussed.

Published by Bioscientifica Ltd. 


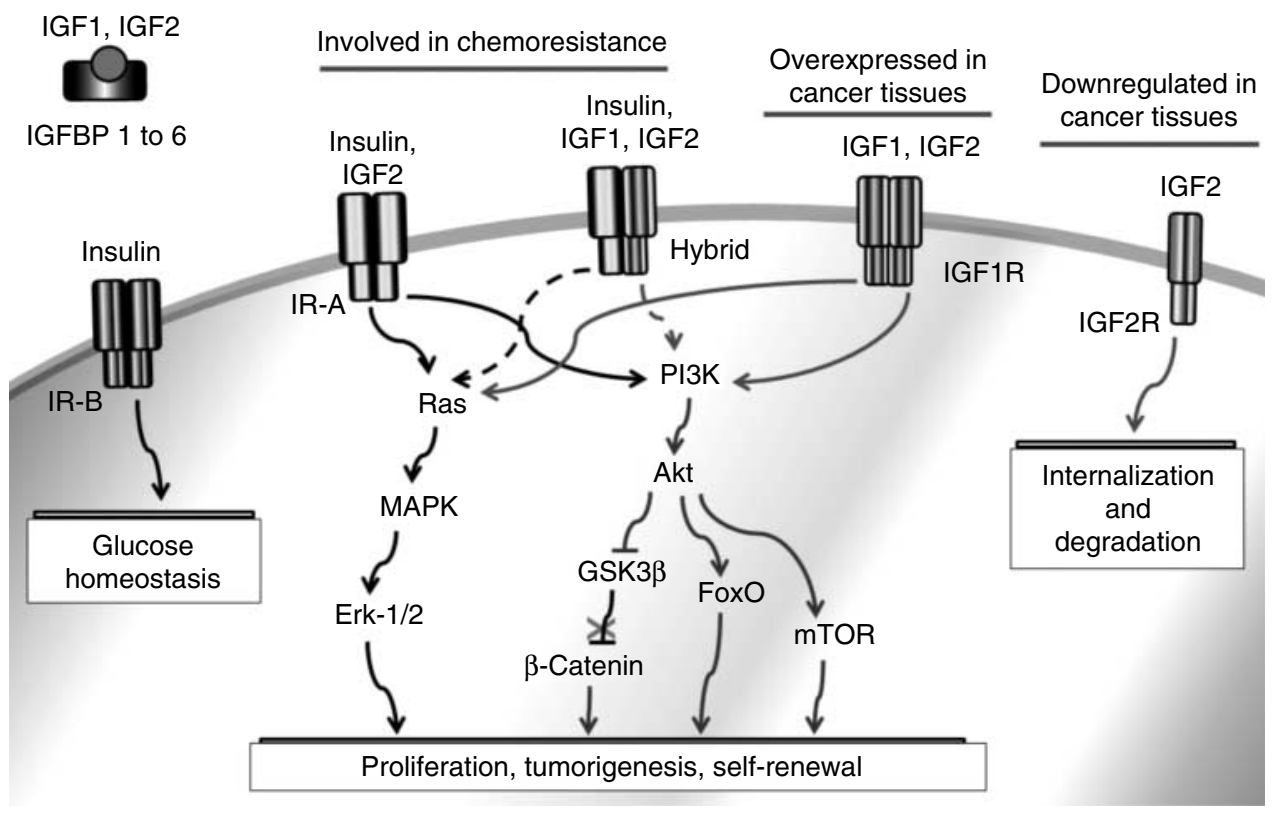

\section{Figure 1}

ILP signaling and cancer. ILP receptors are structurally related tyrosine kinase receptors. Canonical insulin receptor isoform ' $A$ ' (IR-A), isoform 'B' (IR-B), IGF1 receptor (IGF1R), and hybrid receptor (holoreceptors made of combinations of half IGF1R and IR isoforms or other tyrosine kinases) signaling are mediated through downstream pathways like phosphoinositide 3-kinase (PI3K)/protein kinase B (Akt)/mammalian target of rapamycin (mTOR), PI3K/Akt/forkhead box O (FoxO), Ras/MAPK/ extracellular signal-related kinase $1 / 2$ (ERK-1/2) pathways, or through

\section{ILPs, insulin resistance, and cancer risk}

\section{ILP molecules and cancer risk}

Data sustaining an association between IGF1 and cancer risk include recent studies from Mora et al. (2011) in elderly, which have suggested that genetic variations in the insulin/IGF1 pathway genes are associated with longevity, dementia, metabolic diseases, and cancer. However, ILP association with cancer risk is still debated, as controversial data have been reported. In a study assessing the link between overall cancer mortality and circulating IGF1 or IGFBP3 levels, no significant association was found (Kaplan et al. 2012). However, another recent clinical study has indicated that IGF1 is positively associated and IGFBP3 is inversely associated with allcause mortality in men with advanced prostate cancer (Rowlands et al. 2012), indicating that levels of IGF1 and IGFBP3 may have potential as prognostic markers in predicting risk of death in men with advanced prostate cancer. A comparable study has revealed a correlation between zinc, IGF1, and IGFBP3 concentrations, and
$\mathrm{PI} 3 \mathrm{~K} /$ Akt-mediated inactivation of glycogen synthase kinase $3 \beta$ (GSK3 $\beta$ ) that results in the accumulation of $\beta$-catenin and in the activation of its downstream targets. The IGF2 receptor (IGF2R) attenuates IGF2 signaling by clearing that molecule from the cell surface without signal transduction. Overexpression of IGF1R signaling and downregulation of IGF2R are commonly reported in cancer, as well as the overexpression of IR-A and hybrid receptor signaling in the presence of abnormally high levels of insulin and IGFs.

prostate-specific antigen in prostate cancer, and findings have indicated that zinc, IGF1, and IGFBP3 can be useful in early diagnosis of prostate cancer (Darago et al. 2011). In addition, other investigators reported that IGFBP3 gene polymorphism would be associated with the susceptibility to develop prostate cancer (Safarinejad et al. 2011a). A report from Price et al. (2012) indicates that increases in circulating IGF1 levels are associated with a significantly increased risk for prostate cancer development. Interestingly, this positive association did not differ depending on the duration of follow-up for cancers diagnosed more than 7 years after blood collection, or by stage, grade, and age at diagnosis or age at blood collection, and raise up the question whether reducing circulating IGF1 levels may affect prostate cancer risk. Moreover, IGF1 serum levels are increased in patients with locally advanced colorectal cancer (pT3 and pT4), in comparison to less advanced (pT2); a higher serum level of IGF1 is observed in patients with poorly differentiated cancers (G3) than in moderately differentiated, and similarly, higher serum levels of IGF1 are found in male

Published by Bioscientifica Ltd. 
patients older than 60 years and in mucigenous colorectal cancers (Kuklinski et al. 2011). The risk of colorectal cancer would also be associated with higher IGF1/IGFBP3 ratio or C-peptide levels (Wu et al. 2011).

A possible explanation for the differences between the observations of the first investigators and the following ones has been provided by studies of Henningson et al. (2011) and Masago et al. (2011). Both studies reported experimental and clinical data suggesting a correlation between interpersonal variability in IGF1 levels and cancer risk. These findings indicate that according to the type of cancer considered and at an individual basis, the importance of ILP molecules for cancer risk evaluation can change. Another illustration can be provided by recent studies in colorectal adenoma. In a first clinical study, only the increases in circulating IGF1 and IGF1/IGFBP3 ratio have been reported to represent a disturbed GH/IGF1 homeostasis, which could favor the development of precancerous lesions such as colorectal adenoma, and to be, therefore, an indicator of the risk of cancer development (Soubry et al. 2012), suggesting that IGF1 is associated with the pivotal precursor to colorectal cancer. On the other hand, in another clinical study, although a positive association between circulating IGF1 levels and the risk of advanced colorectal adenoma was observed as well, IGFBP3 levels and IGF1/IGFBP3 ratio were not indicative of cancer risk, whereas elevated IGF2 levels were indicative instead (Gao et al. 2012). Considering that most studies evaluating the link between ILP molecules and cancer risk have been performed on small cohorts, large prospective studies are required to better characterize the potential roles of ILP molecules for cancer risk evaluation and reduce the bias created by interindividual variability. Interestingly, findings from a populationbased study, where components of the IGF axis did not appear to be risk factors for pancreatic cancer, have indicated that it cannot be excluded that a relatively large amount of IGF1 together with very low levels of IGFBP3 might still be associated with an increase in cancer risk (Rohrmann et al. 2012), given that statistical subanalysis may not reflect the physiopathological reality. Data from a study adopting such approach have indicated that high-grade prostate cancers would be more autonomous and, thus, less sensitive to the action of IGF1 than low-grade cancers (Nimptsch et al. 2011), explaining discrepancies in the findings between different studies and the lack of statistical significance reported by many investigators. Further studies should consider better experimental design to reduce biases in statistical subanalysis and should be designed to analyze the data mainly on the basis of their clinical value and less so on their mathematical/statistical significance.

Similar findings have been reported in other types of cancers. IGF1 and IGF1/IGFBP3 molar ratio might increase mammographic density and thus the risk of developing breast cancer (Campagnoli et al. 1992, Byrne et al. 2000). In familial breast cancer, an association between IGF1 levels and cancer development has been reported (Rosen et al. 1991, Bruning et al. 1995, Pasanisi et al. 2011), and IGF1 may predict higher risk of recurrence in breast cancer survivors (Al-Delaimy et al. 2011). Associations of IGF1 and IGF1/IGFBP3 ratio with mortality in women with breast cancer have also been reported (Duggan et al. 2012, Izzo et al. 2012). However, all these data need to be confirmed in larger breast cancer survivor cohorts, considering that other reports have indicated that serum concentrations of IGF1 and IGFBP3 do not correlate with breast cancer development/risk (Trinconi et al. 2011).

Other controversies have been reported. Although most investigators have reported a positive association between IGF1 level (or IGF1/IGFBP3 ratio) and cancer risk, others have reported significant inverse associations, including in prostate cancer (Alokail et al. 2011) and melanoma (Panasiti et al. 2011, Park et al. 2011b), for example. In addition, whereas large increases in IGFBP1 were reported to significantly raise the risk of overall cancer mortality in patients (Kaplan et al. 2012), global Igfbp1 deletion does not affect prostate cancer development in a $c-M y c$ transgenic mouse model (Gray et al. 2011). These observations emphasize the need for large cohort studies.

\section{Energy balance, insulin resistance, and cancer risk}

Although many independent reports have suggested the existence of a link between energy imbalance and cancer in insulin resistance-associated metabolic disorders, data demonstrating such a direct mechanistic link are lacking. Interestingly, it has been reported that long-term lowprotein, low-calorie diet and endurance exercise, which lowers insulin levels, modulate metabolic factors associated with cancer risk (Fontana et al. 2006). More recent studies have revealed that diets leading to weight gain and hyperinsulinemia increase the expression of IR-A on cancer cells (Algire et al. 2011), indicating that insulin level changes can mediate the effects of energy balance in cancer. A recent meta-analysis assessed the correlation between intentional weight loss and cancer risk reduction (Byers \& Sedjo 2011). The investigators analyzed all available literature reporting changes in cancer risk

Published by Bioscientifica Ltd. 
following intentional weight loss, as well as reports addressing changes in major cancer risk factors, including IGFs and IGFBPs, estrogens, and sex hormone binding globulin (SHBG), as well as inflammatory markers such as C-reactive protein (CRP), tumor necrosis factor- $\alpha$ (TNF- $\alpha$ ), and interleukin 6 (IL6). Interestingly, the findings from this study suggest that cancer incidence was reduced after intentional weight loss in about all observational cohort studies and randomized controlled trials of both dietary interventions and bariatric surgery. In addition, a correlation was observed between intentional weight loss and decrease in estrogen level as well as SHBG level increase with up to threefold reduction in free estradiol from a $10 \%$ weight loss. The weight loss was accompanied by a decrease in pro-inflammatory factor expression, notably, with a comparable 3:1 ratio in CRP levels drop. The reductions in circulating TNF- $\alpha$ and IL6 were consistent as well, although at smaller magnitude. Surprisingly, IGF1 and IGFBP changes observed after weight loss were inconsistent. Collectively, these observations suggest that estrogen and circulating pro-inflammatory factors are the major players in cancer risk decrease caused by body weight loss, unlike IGF1. It has been hypothesized that abnormally high levels of growth factors, adipokines, reactive oxygen species, adhesion factors, and pro-inflammatory cytokines observed under conditions of insulin resistance create a favorable niche for neoplastic tissue survival and cancer stem cell development, with tumors behaving like 'wounds that never heal' to ensure their maintenance (Sakurai \& Kudo 2011, Pollak 2012, Seke Etet et al. 2012). Considering that in most cases both cancer incidence and levels of circulating cancer biomarkers drop relatively rapidly following intentional weight loss (Byers $\&$ Sedjo 2011), the latter should be further investigated as a meaningful approach for cancer risk reduction.

Although there are controversial data, recent findings, mostly from population-based studies, have pointed out a link between glucose metabolism, insulin levels, and cancer risk. For instance, an epidemiological study evaluating pancreatic cancer risk factors has revealed that type 2 diabetes is the third major risk factor for this disease (Li 2012). A recent meta-analysis of observational studies has revealed that insulin resistance is a significant risk factor for endometrial cancer, particularly when associated with high levels of circulating adipokines like adiponectin, leptin, and plasminogen activator inhibitor1 , as well as androgens and inflammatory mediators $(\mathrm{Mu}$ et al. 2012). It is widely accepted that diabetic patients have relatively increased cancer risk as well as worse cancer prognosis, in comparison with individuals without diabetes. However, a recent study involving 25476 patients with type 2 diabetes has not found any association between HbA1c and risks for all cancers or specific types of cancer (Miao Jonasson et al. 2012). Instead, experimental data indicate the overexpression of ILP observed in these patients as a cancer risk factor (Ferguson et al. 2012, Gallagher et al. 2012). The hyperinsulinemia resulting from the body's attempt to compensate insulin resistance in type 2 diabetes may benefit fully insulin-sensitive cancer tissue by substantially increasing their growth through IR-A/IGF1R increased signaling. However, whether type 2 diabetes leads to increased IR-A/IGF1R signaling in neoplastic cells in comparison with normal insulin target tissues is still controversial and requires further studies. Whereas some reports indicate that tumors respond favorably to ILP overexpression (Nagamani \& Stuart 1998, Ferguson et al. 2012, Gallagher et al. 2012), other reports indicate that hyperinsulinemia is associated with only a modest increase in tumor growth rate (Kalme et al. 2003, Algire et al. 2011, Pollak 2012). Further studies investigating ILP signaling role in cancer tissues may provide better understanding of cancer biology and reveal novel therapeutic targets.

\section{ILP molecules and carcinogenesis}

Various striking observations and findings indicating a link between ILP molecules and cancer are summarized in Table 1.

\section{Insulin}

Studies evaluating insulin secretion, as reflected by C-peptide levels, have pointed out a correlation between high plasma concentration of insulin and poor clinical outcome and death in prostate cancer (Ma et al. 2008). A recent study has shown that aldo-keto reductase $1 \mathrm{~B} 10$ (AKR1B10), which plays a critical role in tumor development and progression through promoting lipogenesis and eliminating cytotoxic carbonyls, is induced by mitogen epidermal growth factor (EGF) and insulin through the activator protein-1 (AP-1) signaling pathway in human hepatocellular carcinoma cells (Liu et al. 2012). Most recent reports have also suggested that insulin has mitogenic and anti-apoptotic effects in endometrial cancer, and the activation of IR-A, IR substrate 1 , and Akt is associated with aggressive features (Wang et al. 2012). Proinsulin, the prohormone precursor to insulin characterized by low metabolic activity, binds with high

Published by Bioscientifica Ltd. 
Table 1 Recent striking observations indicating a link between ILPs and cancer risk.

\begin{tabular}{|c|c|}
\hline & Observations \\
\hline Insulin & Association of mutations in insulin/IGF1 pathway genes with cancer (Mora et al. 2011) \\
\hline \multirow{2}{*}{ IR-A } & IR-A upregulation on cancer cells (Algire et al. 2011) \\
\hline & IR-A activation associated with aggressive features in endometrial cancer (Wang et al. 2012) \\
\hline \multirow[t]{2}{*}{ IGF1 } & IGF1 promotes prostate cancer growth (Rabiau et al. 2011, Takahara et al. 2011) \\
\hline & $\begin{array}{l}\text { High IGF1 levels associated with increased risk for prostate cancer (Alokail et al. 2011, Price et al. 2012), } \\
\text { melanoma (Park et al. 2011b), colorectal cancer (Kuklinski et al. 2011, Gao et al. 2012), and breast cancer } \\
\text { (Al-Delaimy et al. 2011) }\end{array}$ \\
\hline IGF1R & IGF1R universal expression in multiple myeloma cells (Barbosa et al. 2011) \\
\hline \multirow[t]{2}{*}{ IGF1/IGFBP3 ratio } & $\begin{array}{l}\text { High IGF1/IGFBP3 ratio associated with increased risk for colorectal cancer (Wu et al. 2011) and melanoma } \\
\text { (Panasiti et al. 2011) }\end{array}$ \\
\hline & $\begin{array}{l}\text { Prognostic marker of death in prostate cancer (Darago et al. 2011, Rowlands et al. 2012) and breast cancer } \\
\text { (Duggan et al. 2012, Izzo et al. 2012, Meggiorini et al. 2012) }\end{array}$ \\
\hline \multirow[t]{2}{*}{ IGFBPs } & $\begin{array}{l}\text { IGFBP3 gene polymorphism association with risk for prostate cancer (Safarinejad et al. 2011a) and bladder } \\
\text { cancer (Safarinejad et al. 2011b) }\end{array}$ \\
\hline & $\begin{array}{l}\text { High IGFBP1 levels associated with overall cancer mortality (Kaplan et al. 2012) } \\
\text { IGFBP5 and IGFBP7 levels predict lung cancer (NSCLC) outcome (Shersher et al. 2011) }\end{array}$ \\
\hline IGF2 & $\begin{array}{l}\text { IGF2 prognostic molecular biomarker in hepatocellular carcinoma (HCC) (El Tayebi et al. 2011), prostate } \\
\text { cancer (Rowlands et al. 2012), and intrathoracic tumors (Thabit et al. 2011) }\end{array}$ \\
\hline IGF2R & $\begin{array}{l}\text { IGF2 mutations associated with risk for oral cancer (Yoon et al. 2012), colon cancer (Hoyo et al. 2012), and } \\
\text { hepatocellular carcinoma (Couvert et al. 2012) }\end{array}$ \\
\hline
\end{tabular}

HCC, hepatitis C-related cirrhosis; IGF1R, IGF1 receptor; IGF2R, IGF2 receptor; IGFBP, IGF-binding protein; IRs, insulin receptors; NSCLC, non-small cell lung cancer.

affinity to IR-A and predominantly activates the ERK/p70S6K mitogenic pathway to a similar degree as insulin; in addition, proinsulin was almost equipotent as insulin in inducing cell proliferation and migration in three human cancer cell lines expressing various IR-A levels (Malaguarnera et al. 2012). IR-A and IGF1R are homologous to tyrosine kinase class oncogenes and share about 60\% homology (Rowzee et al. 2009). IR-A is commonly expressed by tumors, and most cancer cells express IGF1R gene, but activating mutations of these receptors are rare (Avnet et al. 2009, Kim et al. 2012), indicating that ligand-mediated triggering of ILP signaling is mandatory for ILP carcinogenic effect. Unlike IGFs, local production of insulin by tumors is uncommon (Venkateswaran et al. 2007, Klement \& Kammerer 2011). However, a recent study investigating the range of autoinhibitory mechanisms used by tyrosine kinase domains (TKDs) from the IR family has revealed a wide range of expected activating mutations in cancer (Artim et al. 2012).

\section{IGF1}

Experimental data suggest that IGF1 plays a role in carcinogenesis. For instance, clinical and experimental studies have revealed that IGF1 gene is specifically expressed in tumor tissues in prostate cancer (Koutsilieris et al. 1993, Culig et al. 1994, Rabiau et al. 2011). A study performed in lit/lit mice transplanted human prostate cancer xenografts has demonstrated that circulating GH and IGF1 promote androgen-responsive growth, castration-resistant progression, and androgen-independent expansion of human prostate cancer cell xenografts (Takahara et al. 2011). Interestingly, IGF1 successfully promoted prostate cancer growth in a suppressed $\mathrm{GH}$ environment. In lung and breast cancers, an association between the marked expression of phosphorylated/activated IGF1Rs and poor clinical outcome has been reported (Law et al. 2008, Furukawa et al. 2010, Kim et al. 2012). Recent data have also suggested IGF1 involvement in the pathogenesis of various blood cancers. For instance, in multiple myeloma, IGF1R has been reported as one of the major mediators of growth and survival of cancer cells (Jernberg-Wiklund \& Nilsson 2012). In a mouse model of acute myelogenous leukemia, IGF signaling has been reported to contribute to the malignant transformation of hematopoietic progenitors via a mechanism involving the receptor tyrosine kinase FLT3 (Stubbs et al. 2008) and the fusion oncoprotein MLL-AF9 (Jenkins et al. 2012). IGF1R is universally expressed in multiple myeloma cells (Freund et al. 1994, Barbosa et al. 2011), and insulin and IGFs are potent myeloma cell growth factors through insulin/IGF1 hybrid receptor activation (Freund et al. 1993, Sprynski et al. 2010). Moreover, a recent study addressing the effect of five marketed insulin analogs on insulin/IGF1 hybrid receptors have indicated that

Published by Bioscientifica Ltd. 
IR-A/IGF1 hybrid receptors are present in most tissues and mediate biological effects close to those of IGF1R (Pierre-Eugene et al. 2012). The study revealed that the insulin analog glargine displays higher proliferative and anti-apoptotic effects than insulin in the breast cancer cell line MCF-7, probably through IR-A/IGF1R hybrids.

\section{IGF2}

Recent evidence indicates that IGF2R plays a crucial role in cancer prevention attributed to its antagonist role on cellular growth and evidence of loss of heterozygosity in several cancers including breast cancer (Cheng et al. 2009). Loss of function mutations in the gene encoding for this receptor were reported in various cancers, including hepatocellular carcinoma (De Souza et al. 1995); breast carcinoma (Chappell et al. 1997); endometrial, gastric, and colorectal cancers (Ouyang et al. 1997); squamous cell carcinoma (Probst et al. 2009); and ovarian cancer (Kuhlmann et al. 2011). RNA interference with the expression of the bioactive complex mannose-6phosphate (M6P)/IGF2R in urokinase-type plasminogen activator (uPA) or uPA receptor (uPAR) expressing human cancer and endothelial cells results in increased pericellular plasminogen activation, cell adhesion, and higher invasive potential, and M6P/IGF2R silencing also leads to the cell surface accumulation of urokinase and plasminogen, as well as an enhanced expression of alpha $\mathrm{V}$ integrin (Schiller et al. 2009), indicating that M6P/IGF2R controls cell invasion by regulating alpha $\mathrm{V}$ integrin expression and by accelerating uPAR cleavage. Besides, plasminogen activation cascade plays a central role in cell migration and in angiogenesis (Pepper et al. 1987, Takano et al. 1994). Leksa et al. (2012) reported that M6P/IGF2R can control cancer cell migration and impede aberrant angiogenesis (Leksa et al. 2011) by blocking plasminogen activation and modulating its uptake by transforming cells. Furthermore, Probst et al. (2009) have shown that M6P/IGF2R-deficient SCC-VII murine squamous cell carcinoma cells secrete large amounts of pro-invasive lysosomal proteinases, with an impairment of the formation of mature lysosomes. Interestingly, M6P/IGF2R expression reduced the invasive capacity of SCC-VII cells in response to various chemoattractants, indicating that the M6P/IGF2R status influences the metastatic propensity of squamous cell carcinomas. Besides, loss of heterozygosity proximal to the M6P/IGF2R locus is predictive for the presence of disseminated tumor cells in the bone marrow of ovarian cancer patients (Kuhlmann et al. 2011), and M6P/IGF2R restricts liver cell invasion by preventing the pericellular action of M6P-modified proteins in tumorigenic rodent liver cells (Puxbaum et al. 2012). A recent report has elegantly demonstrated that M6P/IGF2R truncation mutants may in fact contribute to the cancer phenotype by decreasing the availability of full-length M6P/IGF2Rs to perform tumor-suppressive functions including internalization of receptor ligands such as IGF2 (Kreiling et al. 2012).

Moreover, overexpressed IGF2 can mediate carcinogenic effects through IR-A (Wang et al. 2012). Notably, IGFs originate from both local and systemic productions in cancer (Fagin et al. 1988, Foulstone et al. 2003) and are commonly expressed by cancer cells (Venkateswaran et al. 2007, Klement \& Kammerer 2011). Morcavallo et al. (2011) performed quantitative proteomics of insulin-A substrates recruited to tyrosine-phosphorylated protein complexes following either insulin or IGF2. Of the 38 substrates identified, 28 substrates had not been previously related to IR-A signaling pathway, and ten were well known ones. Interestingly, whereas 11 substrates were recruited by both ligands, 14 were recruited solely by IGF2 and 13 by insulin alone. Discoidin domain receptors, which are involved in cell migration and tumor metastasis, and ephrin receptor B4, which is involved in cell migration, were predominantly activated by IGF2. In addition, more recent studies performed by the same investigators (Morcavallo et al. 2012) have revealed that insulin and IGF2 also affect IR-A biological responses by differentially regulating the receptor trafficking. For instance, whereas a downregulation of IR substrate 1 was observed after prolonged insulin exposure, no comparable effect was observed with IGF2. Conversely, insulin induced significant receptor internalization following signal transduction whereas IGF2 induced only a modest internalization. Overall, the study observations suggested that the lower affinity of IGF2 for the receptor, which causes a less powerful activation of early downstream effectors in comparison with insulin, also protects the receptor and its substrates from downregulation, thereby resulting in sustained mitogenic stimuli.

\section{Insulin resistance, immune response alterations, and cancer: ILP involvement}

\section{Immune response alterations and carcinogenesis}

ILP molecules have been reported to play a crucial role in altered inflammatory responses to infectious challenge commonly observed in insulin resistance-related metabolic disorders (Fenton et al. 2009, Bitar \& Al-Mulla 2012).

Published by Bioscientifica Ltd. 
Some of the commonly reported alterations in obesity and type 2 diabetes include deregulated lymphopoiesis and lymphocyte proliferation, altered antigen presentation, and altered pathogen recognition (Mandel \& Mahmoud 1978, Chandra 1981), which are caused at least in part by an aberrant adipocyte-leukocyte cross talk (Stienstra et al. 2011). Experimental evidence suggests that the abnormally high number of inflammatory cells in adipose tissue of obese subjects and type 2 diabetes patients may promote systemic inflammation and a microenvironment favorable for neoplastic cell survival and proliferation. For instance, aberrant alveolar macrophages contribute to worsening lung infection and autoimmunity in type 2 diabetes patients (Sunahara \& Martins 2012). Fritz et al. (2011) have recently demonstrated that alveolar macrophages release IGF1, which stimulates neoplastic mouse lung cell proliferation through PI3K/Akt and MAPK/ERK activation. Interestingly, their findings also indicate that combining macrophage ablation therapy with IGF1R, MEK, and/or PI3K inhibition may improve therapeutic response in human lung cancer. On the basis of comparable findings, it has been hypothesized that high levels of circulating inflammatory factors and ILPs cause adipocyte activation, resulting in the release of pro-inflammatory adipokines, free fatty acids, and chemoattractant factors that attract and trap circulating macrophages into fat tissue; then, infiltrating macrophages would amplify the adipocyte signals, resulting in immune response deregulation (Glass \& Olefsky 2012). Experimental data sustaining this theory also include early reports indicating an improvement of immune response following gastric bypass and weight loss (Grace et al. 1986, Tanaka et al. 1993), and recent reports indicating that a high-fat diet increases aberrant angiogenesis, solid tumor growth, and lung metastasis of CT26 colon cancer cells, even in obesityresistant BALB/c mice (Park et al. 2011a), and comparable studies indicating that decreased systemic IGF1 in response to calorie restriction modulates murine tumor cell growth, NF- $\mathrm{B}$ activation, and inflammation-related gene expression (Harvey et al. 2012). In addition, adipocyte-released IGF1 is regulated by glucose and fatty acids and controls breast cancer cell growth in vitro (D'Esposito et al. 2012).

Moreover, the activation of the IGF1R and IR-A signaling target mTOR accounts for at least part of the enhancing effects of obesity on mammary tumor growth (Gallagher et al. 2012), and such effects are reversed by the mTOR inhibitor RAD001 in mouse models of obesity (De Angel et al. 2012). Besides, macrophages express leptin receptors, which play a crucial role in the innate immune response, particularly through activation of JAK-STAT signaling pathway, which is the canonical cytokine receptor signaling pathway, and through activation of ILP signaling downstream targets like PI3K/Akt/mTOR/p70S6K and MAPK/ERKs pathways (Lee et al. 1999, Algire et al. 2011). Leptin triggers the production of proinflammatory factors, such as TNF- $\alpha$, IL1, IL6, and leukotriene B4 that normally result in the increase of immune cell survival, maturation, and proliferation. However, the drastically increased levels of circulating leptin characteristic of obesity and type 2 diabetes may cause cell adherence and pathogen recognition impairments instead and probably contribute to the occurrence of abnormally increased levels of pro-inflammatory factors in these pathological conditions (Ropelle et al. 2010). Other recent studies have shown alterations in rolling, adhesion, and migration of leukocytes to the site of infection in diabetic mice (Spiller et al. 2012).

Notably, insulin resistance treatment improves some indices of immune response both in experimental models and in patients. Recent clinical studies involving patients with morbid obesity and type 2 diabetes mellitus have revealed a reduction in endotoxemia, oxidative stress, systemic inflammation, as well as insulin resistance following gastric bypass surgery (Monte et al. 2012). Recent findings in monocytes from obese subjects, where insulin resistance is associated with increases in oxidative stress and activation of proinflammatory signaling molecules like c-Jun $\mathrm{NH}$ (2)terminal kinase (JNK) and nuclear factor $\kappa \mathrm{B}$ inhibitor kinase (IKK- $\beta)$, indicate that the induction of stress kinase inhibitors such as heat-shock proteins (Hsp) 72 and Hsp27 improves insulin signaling via inhibition of stress kinases and the reduction of serine phosphorylated/inactivated IR substrate 1 (Simar et al. 2012). Studies in obese mice have shown that targeting inflammatory dendritic cells improves insulin response resistance through NF-кB (Yekollu et al. 2011). However, despite these promising observations, whether insulin resistance treatment or direct pharmacological targeting of inflammation suffices to completely restore the immune response in obese subjects and diabetic patients is still controversial. Some recent clinical studies have reported insulin resistance treatment failure to restore the immune response in several cases (Fernandez-Real \& Pickup 2012, Karagiannis et al. 2012), indicating that mechanisms accounting for immune deregulation in insulin resistance-related metabolic disorders are complex and require further studies.

Published by Bioscientifica Ltd. 


\section{Insulin resistance, infection, and cancer}

In the last decades, a substantial body of evidence from humans and animal models has indicated a link between insulin resistance and impaired immune response to infectious challenges. The deregulation of pathogen recognition in insulin resistance-associated conditions and diseases (Lee et al. 1999) induce the body to trigger a sustained inflammatory response against mutualistic microorganism of the intestinal gut, such as the stomach common bacterium Helicobacter pylori (Grote et al. 2012, Wang et al. 2012). An increasing body of evidence from epidemiological studies has suggested an association between diabetes mellitus and $H$. pylori infection (Jeon et al. 2012). These data further suggest that beyond the high-fat diet hypothesis (Oldham 2011), this microorganism may account as a causative agent for the ongoing diabetes mellitus pandemic (Campbell 2011). In addition, $H$. pylori infection has also been implicated in carcinogenesis; however, the actual mechanism on how the bacterium causes cancer is still controversial. For instance, $H$. pylori has been reported to confer protective effects against esophageal cancer (Islami \& Kamangar 2008), but on the other hand, together with hepatitis B and $C$ viruses, and human papillomaviruses, the bacterium is responsible for about a third of all cancers attributable to infections, mainly including gastric, liver, and cervix uteri cancers (de Martel et al. 2012, Sakitani et al. 2012). In addition, silent infection with $H$. pylori is a source of pro-inflammatory cytokines and IGF1 in hyperinsulinemia conditions (Aguilera et al. 2004, Ozen et al. 2011). Unraveling the precise role of ILP molecules in $H$. pylori-related carcinogenesis may provide novel pharmacological targets for microorganism-related cancers.

Hepatitis C virus has also been reported to cause permanent liver damage and hepatocellular carcinoma (Amitrano et al. 1990, Farinati et al. 1992), at least in part through oxidative stress, inflammatory response, and insulin resistance-related mechanisms (Nishida \& Goel 2011, de Martel et al. 2012, Oliveira et al. 2012). Interestingly, a recent clinical study has provided evidence for metabolic syndrome in nonobese and nondiabetic patients with chronic hepatitis C virus genotype 1 infection; this metabolic syndrome was associated with overweight, increased abdominal fat, hypertension, and insulin resistance (Oliveira et al. 2012). Early clinical studies and studies from animal models suggested an association of hepatitis $C$ virus with insulin resistance, and in a more recent study, an association of the virus nonstructural protein 5A (NS5A) with insulin resistance has been reported (Badar et al. 2012). Furthermore, positive changes in adipokine levels and insulin sensitivity have been observed following antiviral therapy targeting hepatitis $C$ genotype 4 (Khattab et al. 2012), suggesting a direct role of the virus in the insulin resistance that accompany the infection. Interestingly, an in vitro study has shown that hepatitis $C$ virus can induce insulin resistance by inhibiting IR substrate 1 function, i.e. ILP receptor metabolic activity, and through activation of the mTOR/S6K1 signaling pathway (Bose et al. 2012). Another study has revealed a significant proteasomal degradation of IR substrate 1 protein triggered by NS5A in a dosedependent way (Alberstein et al. 2012). In addition, depletion in levels of circulating IGF1 has been observed in this viral infection (Helaly et al. 2011). Altogether, these observations point out hepatitis $\mathrm{C}$ virus as a causative agent of insulin resistance. Furthermore, given the previously discussed ability of insulin resistance to decrease metabolic and increase pro-carcinogenic effects of ILP signaling, insulin resistance may play a crucial role in the chemoresistance observed in hepatitis C-related hepatocarcinoma, and therefore, anti-ILP strategies may prove efficient against this disease.

\section{ILP signaling, insulin resistance, and cancer treatment}

\section{ILP targeting as anticancer strategy}

ILP signaling via the PI3K/Akt/mTOR pathway is a potential therapeutic target for many cancer types, including breast and prostate cancers (Alvino et al. 2011, Tzivion et al. 2011). Many drug candidates targeting ILPs have entered clinical trials, and ILP targeting appears to be a promising anticancer strategy. Clinical trials evaluating the drugs targeting ILPs have been recently reviewed (Pollak 2012, Tognon \& Sorensen 2012). Antibodies specifically targeting IGF1R are already in phase III trials, whereas other classes are in less advanced phases (Gualberto \& Pollak 2009, Kalra et al. 2012). In addition, a phase II study addressing the efficiency of IGF1 antibody figitumumab in non-small-cell lung cancer patients have shown that only patients with abnormally high levels of IGF1 and low levels of IGFBP1 can have a substantial improvement following treatment (Gualberto et al. 2011), indicating that IGF1/IGFBP1 ratio can be predictive of figitumumab clinical benefit. Cixutumumab (IMC-A12), another MAB specifically targeting IGF1R, is relatively safe and enhances the tumor growth inhibitory and

Published by Bioscientifica Ltd. 
pro-apoptotic effects of several chemotherapeutics (Rowinsky et al. 2011, Kalra et al. 2012). However, hyperglycemia and hyperinsulinemia have been reported in some patients, together with increases in GH secretion (Gualberto \& Pollak 2009), indicating pituitary gland attempts to compensate for the lack of IGF1 signaling feedback. Compensatory increases in IR-A following IGF1R silencing and altered insulin B expression resulting respectively in chemoresistance and perturbations in glucose homeostasis were reported as well.

Besides, small-molecule tyrosine kinase inhibitors aiming at targeting IGF1R activity have also been developed. Tremendous undesired effects, and in particular severe metabolic toxicity similar to diabetes mellitus complications, were expected from these molecules that tend to inhibit all ILP activity. Instead, evidence from early clinical experience indicates that these agents are safe and, therefore, promising, given their broader range of receptor inhibition (Chan et al. 2011, Zhou et al. 2011). The mechanisms explaining the absence of the expected side effects still are to be unraveled, even though some plausible explanations have been suggested. For instance, the low penetration of major sites of insulin-stimulated glucose disposition such as the muscle and the incomplete inhibition of ILP receptor signaling have been hypothesized (Dool et al. 2011).

The downstream targets of the canonical ILP signaling include the survival pathway PI3K/Akt that can activate downstream targets like mTOR and FoxO/BAD/Bcl-2 but also inhibit GSK3 $\beta$, resulting in the activation of the oncogenic $\beta$-catenin signaling pathway (Fleming et al. 2008, Ashihara et al. 2009). In the last decade, PI3K, Akt, mTOR, FoxO, BAD, Bcl-2, $\beta$-catenin, and other signaling molecules involved in cell survival and proliferation have been the subjects of investigation of many studies aiming at unraveling carcinogenic mechanisms. These pathways are targets of most tyrosine kinase receptors, indicating that successful targeting would be potentially effective not only against ILP-related cancers but also against aberrant activations of other major anti-apoptotic signaling networks initiated by non-ILP receptor tyrosine kinases. Anticancer effects of $\beta$-catenin targeting are well known in many cancer types, and anticancer drugs targeting this pathway were developed and include cyclopamine for instance. Similarly, BAD/Bcl-2 pathway is the target of the signaling pathways of many oncogenes, including Notch. Notch signaling blockade is used as anticancer therapy, and effective drugs such as $\gamma$-secretase inhibitors were developed for various cancers (Margheri et al. 2012, Seke Etet et al. 2012). Thus, the ILP signaling inhibition may mediate its anticancer effects, at least in part, by modulating these signaling pathways.

\section{ILPs and cancer chemoresistance}

Resistance to drugs selectively affecting ILP signaling has been reported in many cancers, particularly in advanced cancers characterized by constitutively aggressive behavior, which are not influenced anymore by growth signals such as osteosarcoma (Avnet et al. 2009, Ulanet et al. 2010). For instance, in Ewing's sarcoma, an osteosarcoma type that mostly affects children (Garofalo et al. 2011), resistance to anti-IGF1R has been observed. Garofalo et al. (2011) have reported that chemoresistant cancer cells display an increased proliferative response to insulin accompanied by a decrease in insulin metabolic effects. Given the considerable physiological importance of insulin, drugs targeting ILPs were designed to affect IGF1R and hybrid receptors, sparing IR substrates, indicating that in cancers where IGF2 is overexpressed, chemoresistance due to the activation of anti-apoptotic signaling pathways via IR-A (Morcavallo et al. 2011, Wang et al. 2012) may be observed. Not surprisingly, chemoresistant Ewing's sarcoma cells have been reported to exhibit the ability to switch from IGF1/IGF1R to IGF2/IR-A receptor dependency, in order to maintain the sustained activation of Akt and ERK-1/2, which allows them to proliferate and migrate (Garofalo et al. 2011). Future anticancer therapy selectively targeting insulin substrates activated by IGF2 ligation to IR-A may abrogate the chemoresistance of cancer cells relying on the latter mechanism.

Furthermore, recent studies in medulloblastoma mouse models have pointed out PI3K signaling as a potential way of acquiring resistance to anticancer treatment (Buonamici et al. 2010). Such effect would be mediated through $\beta$-catenin signaling that has shown key roles in the chemoresistance to anticancer drugs in various cancer types (Fleming et al. 2008, Ashihara et al. 2009, Nwabo Kamdje et al. 2012, Seke Etet et al. 2012). In addition, another aspect to consider in the use of anti-ILP strategies for cancer treatment is the redundancy of growth factor signaling in cancer. For example, cancers driven mostly by other receptor types, such as EGF receptor (EGF-R), may be resistant to ILP targeting approach (Schmitz et al. 2012).

Notably, IGF1R signaling may confer chemoresistance to various anticancer agents in solid (Ma et al. 2008, Alvino et al. 2011, Rowinsky et al. 2011) and blood cancers (Ashihara et al. 2009, Rowinsky et al. 2011).

Published by Bioscientifica Ltd. 
Besides, IGFBP3 deficiency due to epigenetic gene silencing mediates the resistance to the anticancer drug cisplatin in non-small-cell lung cancer, through a mechanism involving the IGF1R/PI3K/Akt signaling pathway (Cortes-Sempere et al. 2012). Similarly, IGFBP7 may contribute to leukemia resistance to asparaginase but also to the pathogenic interactions between acute lymphoblastic leukemia stem cells and bone marrow stromal cells (Laranjeira et al. 2012).

\section{Concluding remarks}

In this review, we have examined recent studies of insulin resistance and their implications in carcinogenesis. While some of these data are conflicting, data from recent population-based studies have consistently suggested a strong link between antidiabetic treatment with drugs of the biguanide family and a decrease in cancer incidence and mortality (Suissa 2008, Kiri \& Mackenzie 2009, Tan et al. 2011). As such, insulin, IGFs, and their receptors have been the subject of thorough investigations, particularly because of the ongoing worldwide epidemic of obesity, which is associated with complications like memory impairment (Schmoller et al. 2010, Kullmann et al. 2012), immune system deregulations, diseases like type 2 diabetes (Campbell 2011, Karagiannis et al. 2012), and cancer (Byers \& Sedjo 2011, Spyridopoulos et al. 2012). IR-A and IGF1R mediate their effects through oncogenic PI3K/Akt, Ras/MAPK, and $\beta$-catenin signaling pathways, explaining at least in part their involvement in carcinogenesis, and the ability of overexpressed insulin and IGFs to increase cancer risk in obese subjects or in patients with a history of diabetes in first-degree relatives (see section Insulin-like peptides, insulin resistance, and cancer risk). Experimental evidence indicated that ILPs play a crucial role in cancer stem cell maintenance and chemoresistance, and accordingly, drugs targeting IGF1R have been developed and are currently in clinical trials. However, chemoresistance has been reported, particularly in advanced cancers that are less dependent on growing factors, and in cancer using redundant growth factors for their maintenance. A switch from IGF1/IGF1R to IGF2/IRA signaling would explain at least in part several cases of chemoresistance to various anticancer drugs, besides IGF1R antagonists, indicating that drugs affecting IR-A or IGF2 expression may re-sensitize resistant cells to cancer therapy. Future research should focus on better characterizing the molecular mechanism linking ILPs in cancer pathogenesis, considering their potential for cancer biology understanding and the therapeutic implications.

\section{Declaration of interest}

The authors declare that there is no conflict of interest that could be perceived as prejudicing the impartiality of the review.

\section{Funding}

This research did not receive any specific grant from any funding agency in the public, commercial or not-for-profit sector.

\section{Acknowledgements}

The authors are grateful to their respective institutions for constant support and to Dr Mazzini for his comments during the preparation of the manuscript.

\section{References}

Aguilera A, Codoceo R, Bajo MA, Iglesias P, Diez JJ, Barril G, Cigarran S, Alvarez V, Celadilla O, Fernandez-Perpen A et al. 2004 Eating behavior disorders in uremia: a question of balance in appetite regulation. Seminars in Dialysis 17 44-52. (doi:10.1046/j.0894-0959.2004.16086.x)

Ahmed A, Khan TE, Yasmeen T, Awan S \& Islam N 2012 Metabolic syndrome in type 2 diabetes: comparison of WHO, modified ATPIII \& IDF criteria. Journal of the Pakistan Medical Association 62 569-574.

Alberstein M, Zornitzki T, Zick Y \& Knobler H 2012 Hepatitis C core protein impairs insulin downstream signalling and regulatory role of IGFBP-1 expression. Journal of Viral Hepatitis 19 65-71. (doi:10.1111/j.13652893.2011.01447.x)

Al-Delaimy WK, Flatt SW, Natarajan L, Laughlin GA, Rock CL, Gold EB, Caan BJ, Parker BA \& Pierce JP 2011 IGF1 and risk of additional breast cancer in the WHEL study. Endocrine-Related Cancer 18 235-244. (doi:10.1530/ERC-10-0121)

Aldhafiri F, Al-Nasser A, Al-Sugair A, Al-Mutairi H, Young D \& Reilly JJ 2012 Obesity and metabolic syndrome in adolescent survivors of standard risk childhood acute lymphoblastic leukemia in Saudi Arabia. Pediatric Blood \& Cancer 59 133-137. (doi:10.1002/pbc.24012)

Algire C, Amrein L, Bazile M, David S, Zakikhani M \& Pollak M 2011 Diet and tumor LKB1 expression interact to determine sensitivity to anti-neoplastic effects of metformin in vivo. Oncogene 30 1174-1182. (doi:10.1038/onc.2010.483)

Alokail MS, Al-Daghri NM, Al-Attas OS, Alkharfy KM, Sabico SB \& Ullrich A 2011 Visceral obesity and inflammation markers in relation to serum prostate volume biomarkers among apparently healthy men. European Journal of Clinical Investigation 41 987-994. (doi:10.1111/j.1365-2362. 2011.02496.x)

Alvino CL, Ong SC, McNeil KA, Delaine C, Booker GW, Wallace JC \& Forbes BE 2011 Understanding the mechanism of insulin and insulin-like growth factor (IGF) receptor activation by IGF-II. PLOS ONE 6 e27488. (doi:10.1371/journal.pone.0027488)

Amitrano L, Ascione A, Canestrini C, D'Agostino S, Iaccarino L, Vacca C \& Gigliotti T 1990 Prevalence of antibody to hepatitis C virus (anti-HCV) in chronic liver diseases (CLD) in southern Italy. Italian Journal of Gastroenterology 22 16-18.

Artim SC, Mendrola JM \& Lemmon MA 2012 Assessing the range of kinase autoinhibition mechanisms in the insulin receptor family. Biochemical Journal 448 213-220. (doi:10.1042/BJ20121365)

Ashihara E, Kawata E, Nakagawa Y, Shimazaski C, Kuroda J, Taniguchi K, Uchiyama H, Tanaka R, Yokota A, Takeuchi M et al. 2009 -Catenin small interfering RNA successfully suppressed progression of multiple myeloma in a mouse model. Clinical Cancer Research 15 2731-2738. (doi:10.1158/1078-0432.CCR-08-1350)

Avnet S, Sciacca L, Salerno M, Gancitano G, Cassarino MF, Longhi A, Zakikhani M, Carboni JM, Gottardis M, Giunti A et al. 2009 Insulin http://erc.endocrinology-journals.org DOI: $10.1530 /$ ERC-12-0324
(C) 2013 Society for Endocrinology Printed in Great Britain 
receptor isoform A and insulin-like growth factor II as additional treatment targets in human osteosarcoma. Cancer Research 69 2443-2452. (doi:10.1158/0008-5472.CAN-08-2645)

Badar S, Khubaib B, Idrees M, Hussain A, Awan Z, Butt S, Afzal S, Akram M, Fatima Z, Aftab M et al. 2012 Association of hepatitis C virus with insulin resistance: evidences from animal studies and clinical studies. Hepatitis Monthly 12 11-15.

Bai H, Kang P \& Tatar M 2012 Drosophila insulin-like peptide-6 (dilp6) expression from fat body extends lifespan and represses secretion of Drosophila insulin-like peptide-2 from the brain. Aging Cell 11 978-985. (doi:10.1111/acel.12000)

Barbosa FR, Vieira NL, Lima GA, Wildemberg LE, Portugal R \& Gadelha MR 2011 Hematologic neoplasias and acromegaly. Pituitary 14 377-381. (doi:10.1007/s11102-009-0176-0)

Berry MG \& Helwig FC 1948 Marked insulin resistance in diabetes mellitus. American Journal of Medicine 4 923-926. (doi:10.1016/0002-9343(48) 90490-2)

Bitar MS \& Al-Mulla F 2012 ROS constitute a convergence nexus in the development of IGF1 resistance and impaired wound healing in a rat model of type 2 diabetes. Disease Models \& Mechanisms 5 375-388. (doi:10.1242/dmm.007872)

Blethen SL, White NH, Santiago JV \& Daughaday WH 1981 Plasma somatomedins in children with hyperinsulinism. Journal of Clinical Endocrinology and Metabolism 52 748-750. (doi:10.1210/jcem-52-4-748)

Blundell TL, Bedarkar S, Rinderknecht E \& Humbel RE 1978 Insulin-like growth factor: a model for tertiary structure accounting for immunoreactivity and receptor binding. PNAS 75 180-184. (doi:10.1073/pnas. 75.1.180)

Bolukbasi E, Vass S, Cobbe N, Nelson B, Simossis V, Dunbar DR \& Heck MM 2012 Drosophila poly suggests a novel role for the Elongator complex in insulin receptor-target of rapamycin signalling. Open Biology 2110031. (doi:10.1098/rsob.110031)

Bose SK, Shrivastava S, Meyer K, Ray RB \& Ray R 2012 Hepatitis C virus activates the mTOR/S6K1 signaling pathway in inhibiting IRS-1 function for insulin resistance. Journal of Virology 86 6315-6322. (doi:10.1128/JVI.00050-12)

Bruning PF, Van Doorn J, Bonfrer JM, Van Noord PA, Korse CM, Linders TC \& Hart AA 1995 Insulin-like growth-factor-binding protein 3 is decreased in early-stage operable pre-menopausal breast cancer. International Journal of Cancer 62 266-270. (doi:10.1002/ijc. 2910620306)

Buonamici S, Williams J, Morrissey M, Wang A, Guo R, Vattay A, Hsiao K, Yuan J, Green J, Ospina B et al. 2010 Interfering with resistance to smoothened antagonists by inhibition of the PI3K pathway in medulloblastoma. Science Translational Medicine 2 51ra70. (doi:10.1126/ scitranslmed.3001599)

Byers T \& Sedjo RL 2011 Does intentional weight loss reduce cancer risk? Diabetes, Obesity \& Metabolism 13 1063-1072. (doi:10.1111/j.14631326.2011.01464.x)

Byrne C, Colditz GA, Willett WC, Speizer FE, Pollak M \& Hankinson SE 2000 Plasma insulin-like growth factor (IGF) I, IGF-binding protein 3, and mammographic density. Cancer Research $603744-3748$.

Campagnoli C, Biglia N, Belforte P, Botta D, Pedrini E \& Sismondi P 1992 Post-menopausal breast cancer risk: oral estrogen treatment and abdominal obesity induce opposite changes in possibly important biological variables. European Journal of Gynaecological Oncology 13 139-154.

Campbell AW 2011 The diabetes pandemic. Alternative Therapies in Health and Medicine 17 8-9.

Chan L, Terashima T, Urabe H, Lin F \& Kojima H 2011 Pathogenesis of diabetic neuropathy: bad to the bone. Annals of the New York Academy of Sciences 1240 70-76. (doi:10.1111/j.1749-6632.2011.06309.x)

Chandra RK 1981 Immune response in overnutrition. Cancer Research 41 3795-3796.

Chappell SA, Walsh T, Walker RA \& Shaw JA 1997 Loss of heterozygosity at the mannose 6-phosphate insulin-like growth factor 2 receptor gene correlates with poor differentiation in early breast carcinomas. British Journal of Cancer 76 1558-1561. (doi:10.1038/bjc.1997.596)

Cheng I, Stram DO, Burtt NP, Gianniny L, Garcia RR, Pooler L, Henderson BE, Le ML \& Haiman CA 2009 IGF2R missense single-nucleotide polymorphisms and breast cancer risk: the multiethnic cohort study. Cancer Epidemiology, Biomarkers \& Prevention 18 1922-1924. (doi:10.1158/1055-9965.EPI-09-0253)

Cortes-Sempere M, de Miguel MP, Pernia O, Rodriguez C, de Castro CJ, Nistal M, Conde E, Lopez-Rios F, Belda-Iniesta C, Perona R et al. 2012 IGFBP-3 methylation-derived deficiency mediates the resistance to cisplatin through the activation of the IGFIR/Akt pathway in non-small cell lung cancer. Oncogene [in press]. (doi:10.1038/onc.2012.146)

Couvert P, Carrie A, Tezenas du MS, Vaysse J, Sutton A, Barget N, Trinchet JC, Beaugrand M, Ganne N, Giral P et al. 2012 Insulin-like growth factor 2 gene methylation in peripheral blood mononuclear cells of patients with hepatitis $\mathrm{C}$ related cirrhosis or hepatocellular carcinoma. Clinics and Research in Hepatology and Gastroenterology 36 345-351. (doi:10.1016/j.clinre.2012.06.013)

Culig Z, Hobisch A, Cronauer MV, Radmayr C, Trapman J, Hittmair A, Bartsch G \& Klocker H 1994 Androgen receptor activation in prostatic tumor cell lines by insulin-like growth factor-I, keratinocyte growth factor, and epidermal growth factor. Cancer Research 54 5474-5478.

Darago A, Sapota A, Matych J, Nasiadek M, Skrzypinska-Gawrysiak M \& Kilanowicz A 2011 The correlation between zinc and insulin-like growth factor 1 (IGF-1), its binding protein (IGFBP-3) and prostatespecific antigen (PSA) in prostate cancer. Clinical Chemistry and Laboratory Medicine 49 1699-1705. (doi:10.1515/CCLM.2011.651)

De Angel RE, Conti CJ, Wheatley KE, Brenner AJ, Otto G, Degraffenried LA \& Hursting SD 2012 The enhancing effects of obesity on mammary tumor growth and Akt/mTOR pathway activation persist after weight loss and are reversed by RAD001. Molecular Carcinogenesis [in press]. (doi:10.1002/mc.21878)

De Souza AT, Hankins GR, Washington MK, Fine RL, Orton TC \& Jirtle RL 1995 Frequent loss of heterozygosity on 6q at the mannose 6-phosphate/insulin-like growth factor II receptor locus in human hepatocellular tumors. Oncogene 10 1725-1729.

D'Esposito V, Passaretti F, Hammarstedt A, Liguoro D, Terracciano D, Molea G, Canta L, Miele C, Smith U, Beguinot F et al. 2012 Adipocytereleased insulin-like growth factor-1 is regulated by glucose and fatty acids and controls breast cancer cell growth in vitro. Diabetologia $\mathbf{5 5}$ 2811-2822. (doi:10.1007/s00125-012-2629-7)

Dool CJ, Mashhedi H, Zakikhani M, David S, Zhao Y, Birman E, Carboni JM, Gottardis M, Blouin MJ \& Pollak M 2011 IGF1/insulin receptor kinase inhibition by BMS-536924 is better tolerated than alloxan-induced hypoinsulinemia and more effective than metformin in the treatment of experimental insulin-responsive breast cancer. Endocrine-Related Cancer 18 699-709. (doi:10.1530/ERC-11-0136)

Duckworth WC, Garcia JV, Liepnieks JJ, Hamel FG, Hermodson MA, Frank BH \& Rosner MR 1989 Drosophila insulin degrading enzyme and rat skeletal muscle insulin protease cleave insulin at similar sites. Biochemistry 28 2471-2477. (doi:10.1021/bi00432a018)

Duggan C, Wang CY, Neuhouser ML, Xiao L, Smith AW, Reding KW, Baumgartner RN, Baumgartner KB, Bernstein L, Ballard-Barbash R et al. 2012 Associations of insulin-like growth factor and insulin-like growth factor binding protein-3 with mortality in women with breast cancer. International Journal of Cancer [in press]. (doi:10.1038/onc.2012.146)

El Tayebi HM, Salah W, El Sayed IH, Salam EM, Zekri AR, Zayed N, Salem ES, Esmat G \& Abdelaziz AI 2011 Expression of insulin-like growth factorII, matrix metalloproteinases, and their tissue inhibitors as predictive markers in the peripheral blood of HCC patients. Biomarkers 16 346-354. (doi:10.3109/1354750X.2011.573095)

Fagin JA, Brown A \& Melmed S 1988 Regulation of pituitary insulin-like growth factor-I messenger ribonucleic acid levels in rats harboring somatomammotropic tumors: implications for growth hormone autoregulation. Endocrinology 122 2204-2210. (doi:10.1210/endo-122$5-2204)$ 
Faria AM \& Almeida MQ 2012 Differences in the molecular mechanisms of adrenocortical tumorigenesis between children and adults. Molecular and Cellular Endocrinology 351 52-57. (doi:10.1016/j.mce.2011.09.040)

Farinati F, Fagiuoli S, De Maria N, Chiaramonte M, Aneloni V, Ongaro S, Salvagnini M \& Naccarato R 1992 Anti-HCV positive hepatocellular carcinoma in cirrhosis. Prevalence, risk factors and clinical features. Journal of Hepatology 14 183-187. (doi:10.1016/0168-8278(92)90156-J)

Fenton JI, Nunez NP, Yakar S, Perkins SN, Hord NG \& Hursting SD 2009 Diet-induced adiposity alters the serum profile of inflammation in C57BL/6N mice as measured by antibody array. Diabetes, Obesity \& Metabolism 11 343-354. (doi:10.1111/j.1463-1326.2008.00974.x)

Ferguson RD, Novosyadlyy R, Fierz Y, Alikhani N, Sun H, Yakar S \& LeRoith D 2012 Hyperinsulinemia enhances c-Myc-mediated mammary tumor development and advances metastatic progression to the lung in a mouse model of type 2 diabetes. Breast Cancer Research 14 R8. (doi:10.1186/bcr3089)

Fernandez-Real JM \& Pickup JC 2012 Innate immunity, insulin resistance and type 2 diabetes. Diabetologia 55 273-278. (doi:10.1007/s00125-0112387-y)

Fleming HE, Janzen V, Lo CC, Guo J, Leahy KM, Kronenberg HM \& Scadden DT 2008 Wnt signaling in the niche enforces hematopoietic stem cell quiescence and is necessary to preserve self-renewal in vivo. Cell Stem Cell 2 274-283. (doi:10.1016/j.stem.2008.01.003)

Fontana L, Klein S \& Holloszy JO 2006 Long-term low-protein, low-calorie diet and endurance exercise modulate metabolic factors associated with cancer risk. American Journal of Clinical Nutrition 84 1456-1462.

Foulstone EJ, Savage PB, Crown AL, Holly JM \& Stewart CE 2003 Adaptations of the IGF system during malignancy: human skeletal muscle versus the systemic environment. Hormone and Metabolic Research 35 667-674. (doi:10.1055/s-2004-814159)

Freund GG, Kulas DT \& Mooney RA 1993 Insulin and IGF-1 increase mitogenesis and glucose metabolism in the multiple myeloma cell line, RPMI 8226. Journal of Immunology 151 1811-1820.

Freund GG, Kulas DT, Way BA \& Mooney RA 1994 Functional insulin and insulin-like growth factor-1 receptors are preferentially expressed in multiple myeloma cell lines as compared to B-lymphoblastoid cell lines. Cancer Research 54 3179-3185.

Fritz JM, Dwyer-Nield LD \& Malkinson AM 2011 Stimulation of neoplastic mouse lung cell proliferation by alveolar macrophage-derived, insulinlike growth factor-1 can be blocked by inhibiting MEK and PI3K activation. Molecular Cancer 10 76. (doi:10.1186/1476-4598-10-76)

Furukawa J, Wraight CJ, Freier SM, Peralta E, Atley LM, Monia BP, Gleave ME \& Cox ME 2010 Antisense oligonucleotide targeting of insulin-like growth factor-1 receptor (IGF-1R) in prostate cancer. Prostate 70 206-218.

Gallagher EJ, Fierz Y, Vijayakumar A, Haddad N, Yakar S \& LeRoith D 2012 Inhibiting PI3K reduces mammary tumor growth and induces hyperglycemia in a mouse model of insulin resistance and hyperinsulinemia. Oncogene 31 3213-3222. (doi:10.1038/onc.2011.495)

Gao Y, Katki H, Graubard B, Pollak M, Martin M, Tao Y, Schoen RE, Church T, Hayes RB, Greene MH et al. 2012 Serum IGF1, IGF2 and IGFBP3 and risk of advanced colorectal adenoma. International Journal of Cancer $\mathbf{1 3 1}$ E105-E113. (doi:10.1002/ijc.26438)

Garofalo C, Manara MC, Nicoletti G, Marino MT, Lollini PL, Astolfi A, Pandini G, Lopez-Guerrero JA, Schaefer KL, Belfiore A et al. 2011 Efficacy of and resistance to anti-IGF-1R therapies in Ewing's sarcoma is dependent on insulin receptor signaling. Oncogene 30 2730-2740. (doi:10.1038/onc.2010.640)

Glass CK \& Olefsky JM 2012 Inflammation and lipid signaling in the etiology of insulin resistance. Cell Metabolism 15 635-645. (doi:10. 1016/j.cmet.2012.04.001)

Grace DM, Harle IA, Rycroft KM \& Sinclair NR 1986 Immune response after gastric bypass and weight loss. Canadian Journal of Surgery 29 284-286.

Gray A, Aronson WJ, Barnard RJ, Mehta H, Wan J, Said J, Cohen P \& Galet C 2011 Global Igfbp1 deletion does not affect prostate cancer development in a c-Myc transgenic mouse model. Journal of Endocrinology 211 297-304. (doi:10.1530/JOE-11-0240)

Grote VA, Kaaks R, Nieters A, Tjonneland A, Halkjaer J, Overvad K, Skjelbo Nielsen MR, Boutron-Ruault MC, Clavel-Chapelon F, Racine A et al. 2012 Inflammation marker and risk of pancreatic cancer: a nested case-control study within the EPIC cohort. British Journal of Cancer 106 1866-1874. (doi:10.1038/bjc.2012.172)

Gualberto A \& Pollak M 2009 Emerging role of insulin-like growth factor receptor inhibitors in oncology: early clinical trial results and future directions. Oncogene 28 3009-3021. (doi:10.1038/onc.2009.172)

Gualberto A, Hixon ML, Karp DD, Li D, Green S, Dolled-Filhart M, Paz-Ares LG, Novello S, Blakely J, Langer CJ et al. 2011 Pre-treatment levels of circulating free IGF-1 identify NSCLC patients who derive clinical benefit from figitumumab. British Journal of Cancer 104 68-74. (doi:10.1038/sj.bjc.6605972)

Hadaegh F, Mohebi R, Cheraghi L, Tohidi M, Moghaddam NB, Bozorogmanesh M, Sheikholeslami F \& Azizi F 2012 Do different metabolic syndrome definitions predict cerebrovascular events and coronary heart disease independent of their components?: 9 years follow-up of the tehran lipid and glucose study Stroke 43 1669-1671. (doi:10.1161/ STROKEAHA.112.650812)

Harvey AE, Lashinger LM, Otto G, Nunez NP \& Hursting SD 2012 Decreased systemic IGF-1 in response to calorie restriction modulates murine tumor cell growth, nuclear factor-kappaB activation, and inflammation-related gene expression. Molecular Carcinogenesis [in press]. (doi:10.1002/mc.21940)

Helaly GF, Hussein NG, Refai W \& Ibrahim M 2011 Relation of serum insulin-like growth factor-1 (IGF-1) levels with hepatitis $C$ virus infection and insulin resistance. Translational Research 158 155-162. (doi:10.1016/j.trsl.2011.04.005)

Henningson M, Hietala M, Torngren T, Olsson H \& Jernstrom H 2011 IGF1 htSNPs in relation to IGF-1 levels in young women from high-risk breast cancer families: implications for early-onset breast cancer. Familial Cancer 10 173-185. (doi:10.1007/s10689-010-9404-z)

Hoyo C, Murphy SK, Schildkraut JM, Vidal AC, Skaar D, Millikan RC, Galanko J, Sandler RS, Jirtle R \& Keku T 2012 IGF2R genetic variants, circulating IGF2 concentrations and colon cancer risk in African Americans and Whites. Disease Markers 32 133-141.

Islami F \& Kamangar F 2008 Helicobacter pylori and esophageal cancer risk: a meta-analysis. Cancer Prevention Research 1 329-338. (doi:10.1158/ 1940-6207.CAPR-08-0109)

Izzo L, Meggiorini ML, Nofroni I, Pala A, De Felice C, Meloni P, Simari T, Izzo S, Pugliese F, Impara L et al. 2012 Insulin-like growth factor-I (IGF-1), IGF-binding protein-3 (IGFBP-3) and mammographic features. Il Giornale di Chirurgia 33 153-162. (doi:10.3233/DMA-2011-0865)

Jenkins CR, Shevchuk OO, Giambra V, Lam SH, Carboni JM, Gottardis MM, Holzenberger M, Pollak M, Humphries RK \& Weng AP 2012 IGF signaling contributes to malignant transformation of hematopoietic progenitors by the MLL-AF9 oncoprotein. Experimental Hematology 40 715.e6-723.e6. (doi:10.1016/j.exphem.2012.05.003)

Jeon CY, Haan MN, Cheng C, Clayton ER, Mayeda ER, Miller JW \& Aiello AE 2012 Helicobacter pylori infection is associated with an increased rate of diabetes. Diabetes Care 35 520-525. (doi:10.2337/dc11-1043)

Jernberg-Wiklund H \& Nilsson K 2012 Targeting the IGF-1R signaling and mechanisms for epigenetic gene silencing in human multiple myeloma. Upsala Journal of Medical Sciences 117 166-177. (doi:10.3109/ 03009734.2012.659293)

Kaidanovich-Beilin O, Cha DS \& McIntyre RS 2012 Crosstalk between metabolic and neuropsychiatric disorders. F1000 Biology Reports 414 (doi:10.3410/B4-14)

Kalme T, Koistinen H, Loukovaara M, Koistinen R \& Leinonen P 2003 Comparative studies on the regulation of insulin-like growth factorbinding protein-1 (IGFBP-1) and sex hormone-binding globulin (SHBG) production by insulin and insulin-like growth factors in human hepatoma cells. Journal of Steroid Biochemistry and Molecular Biology $\mathbf{8 6}$ 197-200. (doi:10.1016/S0960-0760(03)00268-1) 
Kalra N, Zhang J, Yu Y, Ho M, Merino M, Cao L \& Hassan R 2012 Efficacy of anti-insulin-like growth factor I receptor monoclonal antibody cixutumumab in mesothelioma is highly correlated with insulin growth factor-I receptor sites/cell. International Journal of Cancer 131 2143-2152. (doi:10.1002/ijc.27471)

Kaplan RC, Buzkova P, Cappola AR, Strickler HD, McGinn AP, Mercer LD, Arnold AM, Pollak MN \& Newman AB 2012 Decline in circulating insulin-like growth factors and mortality in older adults: cardiovascular health study all-stars study. Journal of Clinical Endocrinology and Metabolism 97 1970-1976. (doi:10.1210/jc.2011-2967)

Karagiannis T, Paschos P, Paletas K, Matthews DR \& Tsapas A 2012 Dipeptidyl peptidase-4 inhibitors for treatment of type 2 diabetes mellitus in the clinical setting: systematic review and meta-analysis. BMJ 344 e1369. (doi:10.1136/bmj.e1369)

Kern M, Wells JA, Stephens JM, Elton CW, Friedman JE, Tapscott EB, Pekala PH \& Dohm GL 1990 Insulin responsiveness in skeletal muscle is determined by glucose transporter (Glut4) protein level. Biochemical Journal 270 397-400.

Khattab MA, Eslam M, Shatat M, Abd-Aalhalim H, Mousa YI, Samir F, Aly H, Shaker O \& Shaker Y 2012 Changes in adipocytokines and insulin sensitivity during and after antiviral therapy for hepatitis C genotype 4 . Journal of Gastrointestinal and Liver Diseases 21 59-65.

Kim JS, Kim ES, Liu D, Lee JJ, Solis L, Behrens C, Lippman SM, Hong WK, Wistuba II \& Lee HY 2012 Prognostic impact of insulin receptor expression on survival of patients with nonsmall cell lung cancer. Cancer 118 2454-2465. (doi:10.1002/cncr.26492)

Kiri VA \& Mackenzie G 2009 Re: "Immortal time bias in pharmacoepidemiology". American Journal of Epidemiology 170 667-668. (doi:10.1093/aje/kwp239)

Klement RJ \& Kammerer U 2011 Is there a role for carbohydrate restriction in the treatment and prevention of cancer? Nutrition and Metabolism $\mathbf{8}$ 75. (doi:10.1186/1743-7075-8-75)

Klusza S \& Deng WM 2011 At the crossroads of differentiation and proliferation: precise control of cell-cycle changes by multiple signaling pathways in Drosophila follicle cells. Bioessays 33 124-134. (doi:10.1002/bies.201000089)

Koutsilieris M, Frenette G, Lazure C, Lehoux JG, Govindan MV \& Polychronakos C 1993 Urokinase-type plasminogen activator: a paracrine factor regulating the bioavailability of IGFs in PA-III cellinduced osteoblastic metastases. Anticancer Research 13 481-486.

Kreiling JL, Montgomery MA, Wheeler JR, Kopanic JL, Connelly CM, Zavorka ME, Allison JL \& Macdonald RG 2012 Dominant-negative effect of truncated mannose 6-phosphate/insulin-like growth factor II receptor species in cancer. FEBS Journal 279 2695-2713. (doi:10.1111/j. 1742-4658.2012.08652.x)

Kuhlmann JD, Schwarzenbach H, Otterbach F, Heubner M, Wimberger P, Worm KH, Kimmig R \& Kasimir-Bauer S 2011 Loss of heterozygosity proximal to the M6P/IGF2R locus is predictive for the presence of disseminated tumor cells in the bone marrow of ovarian cancer patients before and after chemotherapy. Genes, Chromosomes \& Cancer 50 598-605. (doi:10.1002/gcc.20882)

Kuklinski A, Kamocki Z, Cepowicz D, Gryko M, Czyzewska J, Pawlak K \& Kedra B 2011 Relationships between insulin-like growth factor I and selected clinico-morphological parameters in colorectal cancer patients. Polski Przeglad Chirurgiczny 83 250-257. (doi:10.2478/v10035011-0039-z)

Kullmann S, Heni M, Veit R, Ketterer C, Schick F, Haring HU, Fritsche A \& Preissl H 2012 The obese brain: association of body mass index and insulin sensitivity with resting state network functional connectivity. Human Brain Mapping 33 1052-1061. (doi:10.1002/hbm.21268)

Laranjeira AB, de Vasconcellos JF, Sodek L, Spago MC, Fornazim MC, Tone LG, Brandalise SR, Nowill AE \& Yunes JA 2012 IGFBP7 participates in the reciprocal interaction between acute lymphoblastic leukemia and BM stromal cells and in leukemia resistance to asparaginase. Leukemia 26 1001-1011. (doi:10.1038/leu.2011.289)
Law JH, Habibi G, Hu K, Masoudi H, Wang MY, Stratford AL, Park E, Gee JM, Finlay P, Jones HE et al. 2008 Phosphorylated insulin-like growth factor-i/insulin receptor is present in all breast cancer subtypes and is related to poor survival. Cancer Research 68 10238-10246. (doi:10.1158/0008-5472.CAN-08-2755)

Lee FY, Li Y, Yang EK, Yang SQ, Lin HZ, Trush MA, Dannenberg AJ \& Diehl AM 1999 Phenotypic abnormalities in macrophages from leptindeficient, obese mice. American Journal of Physiology 276 C386-C394.

Leksa V, Loewe R, Binder B, Schiller HB, Eckerstorfer P, Forster F, SolerCardona A, Ondrovicova G, Kutejova E, Steinhuber E et al. 2011 Soluble M6P/IGF2R released by TACE controls angiogenesis via blocking plasminogen activation. Circulation Research 108 676-685. (doi:10.1161/CIRCRESAHA.110.234732)

Leksa V, Pfisterer K, Ondrovicova G, Binder B, Lakatosova S, Donner C, Schiller HB, Zwirzitz A, Mrvova K, Pevala V et al. 2012 Dissecting mannose 6-phosphate-insulin-like growth factor 2 receptor complexes that control activation and uptake of plasminogen in cells. Journal of Biological Chemistry 287 22450-22462. (doi:10.1074/jbc.M112.339663)

Li D 2012 Diabetes and pancreatic cancer. Molecular Carcinogenesis 51 64-74. (doi:10.1002/mc.20771)

Liu Z, Yan R, Al-Salman A, Shen Y, Bu Y, Ma J, Luo DX, Huang C, Jiang Y, Wilber A et al. 2012 Epidermal growth factor induces tumour marker AKR1B10 expression through activator protein-1 signalling in hepatocellular carcinoma cells. Biochemical Journal 442 273-282. (doi:10.1042/ BJ20111322)

Ma J, Li H, Giovannucci E, Mucci L, Qiu W, Nguyen PL, Gaziano JM, Pollak M \& Stampfer MJ 2008 Prediagnostic body-mass index, plasma C-peptide concentration, and prostate cancer-specific mortality in men with prostate cancer: a long-term survival analysis. Lancet Oncology 9 1039-1047. (doi:10.1016/S1470-2045(08)70235-3)

Madsen K, Friberg U, Roos P, Eden S \& Isaksson O 1983 Growth hormone stimulates the proliferation of cultured chondrocytes from rabbit ear and rat rib growth cartilage. Nature 304 545-547. (doi:10.1038/ 304545a0)

Malaguarnera R, Sacco A, Voci C, Pandini G, Vigneri R \& Belfiore A 2012 Proinsulin binds with high affinity the insulin receptor isoform $\mathrm{A}$ and predominantly activates the mitogenic pathway. Endocrinology 153 2152-2163. (doi:10.1210/en.2011-1843)

Mandel MA \& Mahmoud AA 1978 Impairment of cell-mediated immunity in mutation diabetic mice $(\mathrm{db} / \mathrm{db})$. Journal of Immunology 120 1375-1377.

Margheri M, Pacini N, Tani A, Nosi D, Squecco R, Dama A, Masala E, Francini F, Zecchi-Orlandini S \& Formigli L 2012 Combined effects of melatonin and all-trans retinoic acid and somatostatin on breast cancer cell proliferation and death: molecular basis for the anticancer effect of these molecules. European Journal of Pharmacology 681 34-43. (doi:10.1016/j.ejphar.2012.02.011)

de Martel C, Ferlay J, Franceschi S, Vignat J, Bray F, Forman D \& Plummer M 2012 Global burden of cancers attributable to infections in 2008: a review and synthetic analysis. Lancet Oncology 13 607-615. (doi:10. 1016/S1470-2045(12)70137-7)

Masago K, Fujita S, Togashi Y, Kim YH, Hatachi Y, Fukuhara A, Nagai H, Irisa K, Sakamori Y, Mio T et al. 2011 Clinical significance of epidermal growth factor receptor mutations and insulin-like growth factor 1 and its binding protein 3 in advanced non-squamous non-small cell lung cancer. Oncology Reports 26 795-803. (doi:10.3892/or.2011.1354)

Meggiorini ML, Cipolla V, Borgoni G, Nofroni I, Pala A \& de Felice C 2012 Possible effects of insulin-like growth factor-I, IGF-binding protein-3 and IGF-1/IGFBP-3 molar ratio on mammographic density: a crosssectional study. European Journal of Gynaecological Oncology 33 74-78.

Miao Jonasson J, Cederholm J, Eliasson B, Zethelius B, Eeg-Olofsson K \& Gudbjornsdottir S $2012 \mathrm{HbA} 1 \mathrm{C}$ and cancer risk in patients with type 2 diabetes - a nationwide population-based prospective cohort study in Sweden. PLoS ONE 7 e38784. (doi:10.1371/journal.pone.0038784)

Monte SV, Caruana JA, Ghanim H, Sia CL, Korzeniewski K, Schentag JJ \& Dandona P 2012 Reduction in endotoxemia, oxidative and 
inflammatory stress, and insulin resistance after Roux-en-Y gastric bypass surgery in patients with morbid obesity and type 2 diabetes mellitus. Surgery 151 587-593. (doi:10.1016/j.surg.2011.09.038)

Mora M, Perales MJ, Serra-Prat M, Palomera E, Buquet X, Oriola J \& Puig-Domingo M 2011 Aging phenotype and its relationship with IGF-I gene promoter polymorphisms in elderly people living in Catalonia. Growth Hormone \& IGF Research 21 174-180. (doi:10.1016/j.ghir.2011. 03.007)

Morcavallo A, Gaspari M, Pandini G, Palummo A, Cuda G, Larsen MR, Vigneri R \& Belfiore A 2011 Research resource: new and diverse substrates for the insulin receptor isoform A revealed by quantitative proteomics after stimulation with IGF-II or insulin. Molecular Endocrinology 25 1456-1468. (doi:10.1210/me.2010-0484)

Morcavallo A, Genua M, Palummo A, Kletvikova E, Jiracek J, Brzozowski AM, Iozzo RV, Belfiore A \& Morrione A 2012 Insulin and insulin-like growth factor II differentially regulate endocytic sorting and stability of insulin receptor isoform A. Journal of Biological Chemistry 287 11422-11436. (doi:10.1074/jbc.M111.252478)

Mu N, Zhu Y, Wang Y, Zhang H \& Xue F 2012 Insulin resistance: a significant risk factor of endometrial cancer. Gynecologic Oncology 125 751-757. (doi:10.1016/j.ygyno.2012.03.032)

Nagamani M \& Stuart CA 1998 Specific binding and growth-promoting activity of insulin in endometrial cancer cells in culture. American Journal of Obstetrics and Gynecology 179 6-12. (doi:10.1016/S00029378(98)70244-3)

Nimptsch K, Platz EA, Pollak MN, Kenfield SA, Stampfer MJ, Willett WC \& Giovannucci E 2011 Plasma insulin-like growth factor 1 is positively associated with low-grade prostate cancer in the Health Professionals Follow-up Study 1993-2004. International Journal of Cancer 128 660-667. (doi:10.1002/ijc.25381)

Nishida N \& Goel A 2011 Genetic and epigenetic signatures in human hepatocellular carcinoma: a systematic review. Current Genomics 12 130-137. (doi:10.2174/138920211795564359)

Nunez NP, Oh WJ, Rozenberg J, Perella C, Anver M, Barrett JC, Perkins SN, Berrigan D, Moitra J, Varticovski L et al. 2006 Accelerated tumor formation in a fatless mouse with type 2 diabetes and inflammation. Cancer Research 66 5469-5476. (doi:10.1158/0008-5472.CAN-05-4102)

Nwabo Kamdje AH, Bassi G, Pacelli L, Malpeli G, Amati E, Nichele I, Pizzolo G \& Krampera M 2012 Role of stromal cell-mediated Notch signaling in CLL resistance to chemotherapy. Blood Cancer Journal 2 e73. (doi:10.1038/bcj.2012.17)

Oldham S 2011 Obesity and nutrient sensing TOR pathway in flies and vertebrates: functional conservation of genetic mechanisms. Trends in Endocrinology and Metabolism 22 45-52. (doi:10.1016/j.tem. 2010.11.002)

Oliveira LP, Jesus RP, Boulhosa RS, Mendes CM, Lyra AC \& Lyra LG 2012 Metabolic syndrome in patients with chronic hepatitis $C$ virus genotype 1 infection who do not have obesity or type 2 diabetes. Clinics 67 219-223. (doi:10.6061/clinics/2012(03)03)

Ouyang H, Shiwaku HO, Hagiwara H, Miura K, Abe T, Kato Y, Ohtani H, Shiiba K, Souza RF, Meltzer SJ et al. 1997 The insulin-like growth factor II receptor gene is mutated in genetically unstable cancers of the endometrium, stomach, and colorectum. Cancer Research $\mathbf{5 7}$ 1851-1854.

Ozen A, Furman A, Berber M, Karatepe HO, Mutlu N, Saricoban HE \& Buyukgebiz B 2011 The effect of Helicobacter pylori and economic status on growth parameters and leptin, ghrelin, and insulin-like growth factor (IGF)-I concentrations in children. Helicobacter 16 55-65. (doi:10.1111/j.1523-5378.2010.00814.x)

Panasiti V, Naspi A, Devirgiliis V, Curzio M, Roberti V, Curzio G, Gobbi S, Calvieri S \& Londei P 2011 Correlation between insulin-like growth factor binding protein-3 serum level and melanoma progression. Journal of the American Academy of Dermatology 64 865-872. (doi:10.1016/j.jaad.2010.03.035)

Park H, Kim M, Kwon GT, Lim DY, Yu R, Sung MK, Lee KW, Daily JW, III \& Park JH 2011 $a$ A high-fat diet increases angiogenesis, solid tumor growth, and lung metastasis of CT26 colon cancer cells in obesityresistant BALB/c mice. Molecular Carcinogenesis 51 869-880. (doi:10.1002/mc.20856)

Park SL, Setiawan VW, Kanetsky PA, Zhang ZF, Wilkens LR, Kolonel LN \& Le ML $2011 b$ Serum insulin-like growth factor-I and insulin-like growth factor binding protein-3 levels with risk of malignant melanoma. Cancer Causes \& Control 22 1267-1275. (doi:10.1007/s10552-011-9800-1)

Pasanisi P, Bruno E, Venturelli E, Manoukian S, Barile M, Peissel B, De Giacomi C, Bonanni B, Berrino J \& Berrino F 2011 Serum levels of IGF-I and BRCA penetrance: a case control study in breast cancer families. Familial Cancer 10 521-528. (doi:10.1007/s10689-011-9437-y)

Pepper MS, Vassalli JD, Montesano R \& Orci L 1987 Urokinase-type plasminogen activator is induced in migrating capillary endothelial cells. Journal of Cell Biology 105 2535-2541. (doi:10.1083/jcb.105.6. 2535)

Pezzino V, Trischitta V, Purrello F \& Vigneri R 1982 Effect of metformin on insulin binding to receptors in cultured human lymphocytes and cancer cells. Diabetologia 23 131-135. (doi:10.1007/BF01271174)

Pierre-Eugene C, Pagesy P, Nguyen TT, Neuille M, Tschank G, Tennagels N, Hampe C \& Issad T 2012 Effect of insulin analogues on insulin/IGF1 hybrid receptors: increased activation by glargine but not by its metabolites M1 and M2. PLoS ONE 7 e41992. (doi:10.1371/journal. pone.0041992)

Pollak M 2012 The insulin and insulin-like growth factor receptor family in neoplasia: an update. Nature Reviews. Cancer 12 159-169. (doi:10.1038/nrc3215)

Price AJ, Allen NE, Appleby PN, Crowe FL, Travis RC, Tipper SJ, Overvad K, Gronbaek H, Tjonneland A, Johnsen NF et al. 2012 Insulin-like growth factor-I concentration and risk of prostate cancer: results from the european prospective investigation into cancer and nutrition. Cancer Epidemiology, Biomarkers \& Prevention 21 1531-1541. (doi:10.1158/ 1055-9965.EPI-12-0481-T)

Probst OC, Puxbaum V, Svoboda B, Leksa V, Stockinger H, Mikula M, Mikulits W \& Mach L 2009 The mannose 6-phosphate/insulin-like growth factor II receptor restricts the tumourigenicity and invasiveness of squamous cell carcinoma cells. International Journal of Cancer $\mathbf{1 2 4}$ 2559-2567. (doi:10.1002/ijc.24236)

Puxbaum V, Nimmerfall E, Bauerl C, Taub N, Blaas PM, Wieser J, Mikula M, Mikulits W, Ng KM, Yeoh GC et al. 2012 M6P/IGF2R modulates the invasiveness of liver cells via its capacity to bind mannose 6-phosphate residues. Journal of Hepatology 57 337-343. (doi:10.1016/j. jhep.2012.03.026)

Rabiau N, Dechelotte P, Adjakly M, Kemeny JL, Guy L, Boiteux JP, Kwiatkowski F, Bignon YJ \& Bernard-Gallon D 2011 BRCA1, BRCA2, AR and IGF-I expression in prostate cancer: correlation between RT-qPCR and immunohistochemical detection. Oncology Reports 26 695-702. (doi:10.3892/or.2011.1339)

Ricketts HT 1947 Does hyperglycemia harm the diabetic patient? Medical Clinics of North America 31 267-277.

Rinderknecht E \& Humbel RE 1978 Primary structure of human insulin-like growth factor II. FEBS Letters 89 283-286. (doi:10.1016/0014-5793(78) 80237-3)

Rohrmann S, Grote VA, Becker S, Rinaldi S, Tjonneland A, Roswall N, Gronbaek H, Overvad K, Boutron-Ruault MC, Clavel-Chapelon F et al. 2012 Concentrations of IGF-I and IGFBP-3 and pancreatic cancer risk in the European Prospective Investigation into Cancer and Nutrition. British Journal of Cancer 106 1004-1010. (doi:10.1038/bjc.2012.19)

Ropelle ER, Flores MB, Cintra DE, Rocha GZ, Pauli JR, Morari J, de Souza CT, Moraes JC, Prada PO, Guadagnini D et al. 2010 IL-6 and IL-10 antiinflammatory activity links exercise to hypothalamic insulin and leptin sensitivity through IKK $\beta$ and ER stress inhibition. PLoS Biology 8 (8) pii: e1000465. (doi:10.1371/journal.pbio.1000465)

Rosen N, Yee D, Lippman ME, Paik S \& Cullen KJ 1991 Insulin-like growth factors in human breast cancer. Breast Cancer Research and Treatment 18 (Suppl 1) S55-S62. (doi:10.1007/BF02633529) 
Rowinsky EK, Schwartz JD, Zojwalla N, Youssoufian H, Fox F, Pultar P, Novosyadlyy R, Cosaert J \& Ludwig DL 2011 Blockade of insulin-like growth factor type-1 receptor with cixutumumab (IMC-A12): a novel approach to treatment for multiple cancers. Current Drug Targets 12 2016-2033. (doi:10.2174/138945011798829401)

Rowlands MA, Holly JM, Hamdy F, Phillips J, Goodwin L, Marsden G, Gunnell D, Donovan J, Neal DE \& Martin RM 2012 Serum insulinlike growth factors and mortality in localised and advanced clinically detected prostate cancer. Cancer Causes \& Control 23 347-354. (doi:10.1007/s10552-011-9883-8)

Rowzee AM, Ludwig DL \& Wood TL 2009 Insulin-like growth factor type 1 receptor and insulin receptor isoform expression and signaling in mammary epithelial cells. Endocrinology 150 3611-3619. (doi:10.1210/ en.2008-1473)

Safarinejad MR, Shafiei N \& Safarinejad S 2011 $a$ Relationship of insulin-like growth factor (IGF) binding protein-3 (IGFBP-3) gene polymorphism with the susceptibility to development of prostate cancer and influence on serum levels of IGF-I, and IGFBP-3. Growth Hormone and IGF Research 21 146-154. (doi:10.1016/j.ghir.2011.03.008)

Safarinejad MR, Shafiei N \& Safarinejad SH 2011 $b$ The association between bladder cancer and a single nucleotide polymorphism (rs2854744) in the insulin-like growth factor (IGF)-binding protein-3 (IGFBP-3) gene. Archives of Toxicology 85 1209-1218. (doi:10.1007/s00204-011-0671-8)

Sajid W, Kulahin N, Schluckebier G, Ribel U, Henderson HR, Tatar M, Hansen BF, Svendsen AM, Kiselyov VV, Norgaard P et al. 2011 Structural and biological properties of the Drosophila insulin-like peptide 5 show evolutionary conservation. Journal of Biological Chemistry 286 661-673. (doi:10.1074/jbc.M110.156018)

Sakitani K, Hirata Y, Hayakawa Y, Serizawa T, Nakata W, Takahashi R, Kinoshita H, Sakamoto K, Nakagawa H, Akanuma M et al. 2012 The role of Interleukin-32 in Helicobacter pylori - induced gastric inflammation. Infection and Immunity 80 3795-3803. (doi:10.1128/IAI.00637-12)

Sakurai T \& Kudo M 2011 Signaling pathways governing tumor angiogenesis. Oncology 81 (Suppl 1) 24-29. (doi:10.1159/000333256)

Schiller HB, Szekeres A, Binder BR, Stockinger H \& Leksa V 2009 Mannose 6-phosphate/insulin-like growth factor 2 receptor limits cell invasion by controlling alphaVbeta 3 integrin expression and proteolytic processing of urokinase-type plasminogen activator receptor. Molecular Biology of the Cell 20 745-756. (doi:10.1091/mbc.E08-06-0569)

Schmitz S, Kaminsky-Forrett MC, Henry S, Zanetta S, Geoffrois L, Bompas E, Moxhon A, Mignion L, Guigay J, Knoops L et al. 2012 Phase II study of figitumumab in patients with recurrent and/or metastatic squamous cell carcinoma of the head and neck: clinical activity and molecular response (GORTEC 2008-02). Annals of Oncology 23 2153-2161. (doi:10.1093/annonc/mdr574)

Schmoller A, Hass T, Strugovshchikova O, Melchert UH, Scholand-Engler HG, Peters A, Schweiger U, Hohagen F \& Oltmanns KM 2010 Evidence for a relationship between body mass and energy metabolism in the human brain. Journal of Cerebral Blood Flow and Metabolism 30 1403-1410. (doi:10.1038/jcbfm.2010.48)

Seke Etet PF, Vecchio L \& Nwabo Kamdje AH 2012 Interactions between bone marrow stromal microenvironment and B-chronic lymphocytic leukemia cells: any role for Notch, Wnt and Hh signaling pathways? Cellular Signalling 24 1433-1443. (doi:10.1016/j.cellsig.2012.03.008)

Shersher DD, Vercillo MS, Fhied C, Basu S, Rouhi O, Mahon B, Coon JS, Warren WH, Faber LP, Hong E et al. 2011 Biomarkers of the insulin-like growth factor pathway predict progression and outcome in lung cancer. Annals of Thoracic Surgery 92 1805-1811. (doi:10.1016/j. athoracsur.2011.06.058)

Simar D, Jacques A \& Caillaud C 2012 Heat shock proteins induction reduces stress kinases activation, potentially improving insulin signalling in monocytes from obese subjects. Cell Stress \& Chaperones $\mathbf{1 7}$ 615-621. (doi:10.1007/s12192-012-0336-4)

Soubry A, Il'yasova D, Sedjo R, Wang F, Byers T, Rosen C, Yashin A, Ukraintseva S, Haffner S \& D'Agostino R, Jr 2012 Increase in circulating levels of IGF-1 and IGF-1/IGFBP-3 molar ratio over a decade is associated with colorectal adenomatous polyps. International Journal of Cancer 131 512-517. (doi:10.1002/ijc.26393)

Spiller F, Carlos D, Souto FO, de Freitas A, Soares FS, Vieira SM, Paula FJ, Alves-Filho JC \& Cunha FQ 2012 a1-Acid glycoprotein decreases neutrophil migration and increases susceptibility to sepsis in diabetic mice. Diabetes 61 1584-1591. (doi:10.2337/db11-0825)

Sprynski AC, Hose D, Kassambara A, Vincent L, Jourdan M, Rossi JF, Goldschmidt H \& Klein B 2010 Insulin is a potent myeloma cell growth factor through insulin/IGF-1 hybrid receptor activation. Leukemia $\mathbf{2 4}$ 1940-1950. (doi:10.1038/leu.2010.192)

Spyridopoulos TN, Dessypris N, Antoniadis AG, Gialamas S, Antonopoulos CN, Katsifoti K, Adami HO, Chrousos GP \& Petridou ET 2012 Insulin resistance and risk of renal cell cancer: a case-control study. Hormones 11 308-315.

Stienstra R, van Diepen JA, Tack CJ, Zaki MH, van de Veerdonk FL, Perera D, Neale GA, Hooiveld GJ, Hijmans A, Vroegrijk I et al. 2011 Inflammasome is a central player in the induction of obesity and insulin resistance. PNAS 108 15324-15329. (doi:10.1073/pnas.1100255108)

Stubbs MC, Kim YM, Krivtsov AV, Wright RD, Feng Z, Agarwal J, Kung AL \& Armstrong SA 2008 MLL-AF9 and FLT3 cooperation in acute myelogenous leukemia: development of a model for rapid therapeutic assessment. Leukemia 22 66-77. (doi:10.1038/sj.leu.2404951)

Suissa S 2008 Immortal time bias in pharmaco-epidemiology. American Journal of Epidemiology 167 492-499. (doi:10.1093/aje/kwm324)

Sunahara KK \& Martins JO 2012 Alveolar macrophages in diabetes: friends or foes? Journal of Leukocyte Biology 91 871-876. (doi:10.1189/jlb. 0911488)

Takahara K, Tearle H, Ghaffari M, Gleave ME, Pollak M \& Cox ME 2011 Human prostate cancer xenografts in lit/lit mice exhibit reduced growth and androgen-independent progression. Prostate 71 525-537. (doi:10.1002/pros.21268)

Takano S, Gately S, Neville ME, Herblin WF, Gross JL, Engelhard H, Perricone M, Eidsvoog K \& Brem S 1994 Suramin, an anticancer and angiosuppressive agent, inhibits endothelial cell binding of basic fibroblast growth factor, migration, proliferation, and induction of urokinase-type plasminogen activator. Cancer Research 54 2654-2660.

Talbot K, Wang HY, Kazi H, Han LY, Bakshi KP, Stucky A, Fuino RL, Kawaguchi KR, Samoyedny AJ, Wilson RS et al. 2012 Demonstrated brain insulin resistance in Alzheimer's disease patients is associated with IGF-1 resistance, IRS-1 dysregulation, and cognitive decline. Journal of Clinical Investigation 122 1316-1338. (doi:10.1172/JCI59903)

Tan BX, Yao WX, Ge J, Peng XC, Du XB, Zhang R, Yao B, Xie K, Li LH, Dong $\mathrm{H}$ et al. 2011 Prognostic influence of metformin as first-line chemotherapy for advanced nonsmall cell lung cancer in patients with type 2 diabetes. Cancer 117 5103-5111. (doi:10.1002/cncr.26151)

Tanaka S, Inoue S, Isoda F, Waseda M, Ishihara M, Yamakawa T, Sugiyama A, Takamura Y \& Okuda K 1993 Impaired immunity in obesity: suppressed but reversible lymphocyte responsiveness. International Journal of Obesity and Related Metabolic Disorders 17 631-636.

Thabit H, Healy ML, Royston D, Broe P, Scarramuzzi N, Walsh TN \& Sreenan S 2011 A case of spontaneous hypoglycaemia and impaired glucose tolerance in the same patient. Annals of Clinical Biochemistry 48 183-185. (doi:10.1258/acb.2010.010064)

Tognon CE \& Sorensen PH 2012 Targeting the insulin-like growth factor 1 receptor (IGF1R) signaling pathway for cancer therapy. Expert Opinion on Therapeutic Targets 16 33-48. (doi:10.1517/14728222.2011. 638626)

Trinconi AF, Filassi JR, Soares JM, Jr \& Baracat EC 2011 Evaluation of the insulin-like growth factors (IGF) IGF-I and IGF binding protein 3 in patients at high risk for breast cancer. Fertility and Sterility $\mathbf{9 5}$ 2753-2755. (doi:10.1016/j.fertnstert.2011.02.014)

Tzivion G, Dobson M \& Ramakrishnan G 2011 FoxO transcription factors; regulation by AKT and 14-3-3 proteins. Biochimica et Biophysica Acta 1813 1938-1945. (doi:10.1016/j.bbamcr.2011.06.002)

Ulanet DB, Ludwig DL, Kahn CR \& Hanahan D 2010 Insulin receptor functionally enhances multistage tumor progression and conveys 
intrinsic resistance to IGF-1R targeted therapy. PNAS $\mathbf{1 0 7}$ 10791-10798. (doi:10.1073/pnas.0914076107)

Venkateswaran V, Haddad AQ, Fleshner NE, Fan R, Sugar LM, Nam R, Klotz LH \& Pollak M 2007 Association of diet-induced hyperinsulinemia with accelerated growth of prostate cancer (LNCaP) xenografts. Journal of the National Cancer Institute 99 1793-1800. (doi:10.1093/ jnci/djm231)

Vykoukal D \& Davies MG 2012 Biology of metabolic syndrome in a vascular patient. Vascular 20 156-165. (doi:10.1258/vasc.2011. 201201)

Wang Y, Hua S, Tian W, Zhang L, Zhao J, Zhang H, Zhang W \& Xue F 2012 Mitogenic and anti-apoptotic effects of insulin in endometrial cancer are phosphatidylinositol 3-kinase/Akt dependent. Gynecologic Oncology 125 734-741. (doi:10.1016/j.ygyno.2012.03.012)

Witso E 2012 The role of infection-associated risk factors in prosthetic surgery. Hip International 22 (Suppl 8) S5-S8. (doi:10.5301/HIP.2012. 9564)

Wu K, Feskanich D, Fuchs CS, Chan AT, Willett WC, Hollis BW, Pollak MN \& Giovannucci E 2011 Interactions between plasma levels of 25-hydroxyvitamin D, insulin-like growth factor (IGF)-1 and C-peptide with risk of colorectal cancer. PLOS ONE 6 e28520. (doi:10.1371/ journal.pone.0028520)

Yekollu SK, Thomas R \& O'Sullivan B 2011 Targeting curcusomes to inflammatory dendritic cells inhibits NF-kappaB and improves insulin resistance in obese mice. Diabetes 60 2928-2938. (doi:10.2337/ db11-0275)

Yoon AJ, Zavras AI, Chen MK, Lin CW \& Yang SF 2012 Association between Gly1619ARG polymorphism of IGF2R domain 11 (rs629849) and advanced stage of oral cancer. Medical Oncology 29 682-685. (doi:10.1007/s12032-011-9863-6)

Zhang B \& Roth RA 1991 Binding properties of chimeric insulin receptors containing the cysteine-rich domain of either the insulin-like growth factor I receptor or the insulin receptor related receptor. Biochemistry $\mathbf{3 0}$ 5113-5117. (doi:10.1021/bi00235a001)

Zhou H, Rao J, Lin J, Yin B, Sheng H, Lin F, Zhang N \& Yang L 2011 The insulin-like growth factor-I receptor kinase inhibitor NVP-ADW742 sensitizes medulloblastoma to the effects of chemotherapy. Oncology Reports 25 1565-1571. (doi:10.3892/or.2010.1077)

Received in final form 18 November 2012

Accepted 30 November 2012

Made available online as an Accepted Preprint

3 December 2012 http://erc.endocrinology-journals.org DOI: 10.1530/ERC-12-0324
(C) 2013 Society for Endocrinology Printed in Great Britain
Published by Bioscientifica Ltd. 